\title{
EXPERIMENT'S ON ENSILAGR'
}

CONDUCTED AT ROTHAMSTED;

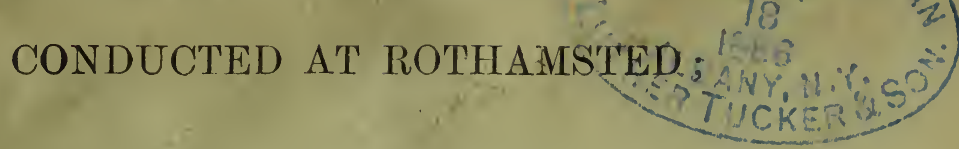

SEASON 1884-5.

BY

SIR J. B. LAWES, BART., LL.D., F.R.S.,

AND

J. H. GILBERT, LL.D., F.R.S.

This paper is, in the main, a reprint of a series of Articles published in the "Agrioultural Gazette," from April 27 to August 10, 1885, as the experiments proceeded; but the order of the sections has been re-arranged, the Tables and text have been revised and corrected, and a more complete summary has been added.
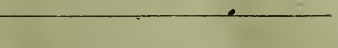
Digitized by the Internet Archive in 2017 with funding from

University of Illinois Urbana-Champaign Alternates 


\title{
EXPERIMENTS ON ENSILAGE, CONDUCTED AT ROTHAMSTED;
}

\author{
SEASON 1884-5.
}

BY

SIR J. B. LAWES, BART., LL.D., F.R.S., AND

J. H. GILBERT, LL.D., F.R.S.

This paper is, in the main, a reprint of a series of Articles published in the "Agricultural Gazette," from April 27 to August 10, 1885, as the experiments proceeded; but the order of the sections has been re-arranged, the Tables and text have been revised and corrected, and a more complete summary has been added.

\author{
L O N D O N : \\ HARRISON AND SONS, ST. MARTIN'S LANE,

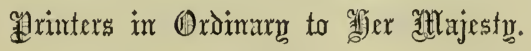




$$
\begin{aligned}
& 635.71 \\
& L 41 \mathrm{e}
\end{aligned}
$$

635.71

L4le 


\section{O N TENTS.}

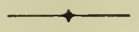

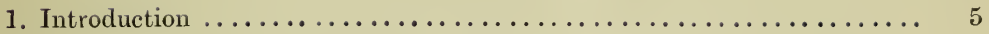

2. The construction, and the filling, of the Silos $\ldots \ldots \ldots \ldots \ldots \ldots \ldots \ldots . . \ldots$

3. Quantity and composition of the Herbage put into the Silos, and of the

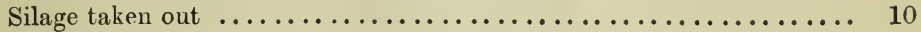

Silo No. 1 (p. 10)

Silo No. 2 (p. 15)

4. The chemical composition of the Silage.................. 19

5. Experiments with Fattening Oxen...................... 24

6. Food required for mere sustenance, for the production of Milk, and for the production of Fattening Increase.................... 28

7. Preliminary Experiments with milking Cows ............... 36

8. Plan and arrangement of the experiments with milking Cows ........ 37

9. The results of the Experiments with milking Cows............. 39

10. Characters and composition of the Milk from the different Foods....... 51

11. Summary, and general conclusions..................... 55 



\title{
EXPERIMENTS ON ENSILAGE,
}

\author{
CONDUCTED AT ROTHAMSTED;
}

S E A S O N $1884-5$.

\section{1.-Introduction.}

AcCording to the "Agricultural Returns," there had, in 1884, been 610 silos constructed in Great Britain, and in 1885, the number was raised to 1183 . It is probable that the greater portion of these are not in the hands of tenant farmers, as even at the best of times they are not over eager in adopting novelties; and now, when the most serious depression exists, they may reanily hesitate to pay even the interest upon a building which after trial might be found to be useless.

It is quite certain that, in some of the statements which have been made by the more enthusiastic advocates of ensilage, there has been much exaggeration, and that the revolution which the silo was to cause in our system of agriculture has yet to take place.

In the early part of 1884, a visit paid to Mr. Gibson's farm at Saffron Walden, where the system of ensilage was in full operation, sufficed to show that the process was worthy of careful investigation; and Mr. Gibson kindly supplied much valuable information, essential for deciding as to the points which required to be investigated. Mr. Gibson's system of feeding was, to give the silage mixed with roots; and when used in this way, with dry food in addition, the milk and butter yielded by the cows were both of good quality. He had also ascertained that clover-silage was superior to that made from pasture grass. 
Although Mr. Gibson's experience is of great practical value, it does not afford much help in regard to the important questionwhat is the value of silage as compared with other foods? A great many points have to be investigated before we can assign to the system of ensilage its proper value in the economy of the farm. We want to know, how good a food silage is generally-and especially the silage made from various crops-both as compared with roots, and with the same crops used in the ordinary way. We further want to know, what are the changes that take place in the pit, and how many pounds of dry matter are taken out for $100 \mathrm{lbs}$. put in; for neither sour nor sweet silage can be made without the destruction of some of the food.

Any one who has had much experience with cows, and the products of a dairy, will understand at once that where the object of experiments is to ascertain the value of one food compared with another, in the production of milk or butter, the subject is surrounded with diffculties. In the feeding of fattening animals, if a sufficient number of them are under experiment, and the food is carefully weighed, it may be expected that the increase in live-weight will give an approximately correct indication of the feeding value of the foods used. With cows, however, not only has every change of food some influence on the yield of milk, but the same food, given in the same quantity, will produce very different amounts of milk with different cows.

It is also well known that milk may be produced at the expense of the substance of the cow herself. The animal may not be even losing weight for a short time, and still may be parting with solid matter which is replaced by water. This being the case, all experiments over short periods, in which one food is substituted for another, are liable to the serious objection, that it is not possible to say what is the source of the change in the milk production. As every cow has a certain milk producing capacity, which cannot be exceeded by any manner of feeding, the animal may be putting on flesh as well as yielding milk with one food, while it may only yield milk without putting on flesh with another food. It is evident that, in the first case, the food possessed a higher nutritive value than in the second; and, consequently, that it might have been reduced without lessening the production of milk. What has been said will be sufficient to show how difficult is the task of carrying out trustworthy experiments for the purpose of determining the influence of different foods on the production of nilk or butter.

In addition to the inquiries respecting the comparative feeding value of silage made from different crops, it is very desirable that investigations should be carefully carried out in regard to the rela- 
tion of food to the milk produced. In the Rothamsted dairy, as probably in all dairies, some rongh and ready plan is adopted for increasing or diminishing the more costly foods according to the amount of milk or butter yielded; but we are not aware of any experiments in which the rise and fall of both milk and food have been made the subject of careful inquiry.

Our experiments on the feeding of cows with silage were commenced in December, 1884, with red clover-silage, followed later with meadow-grass-silage, and they were continued until the cows went out to grass in the spring. Next year we propose to repeat some of the experiments, with different foods, as it is very desirable that the comparison between a corn crop cut green and put into a silo, and the same crop left to ripen, should be made the subject of investigation. Oats will probably be the crop selected for this purpose.

It is contrary to our usual plan, to publish the results of our experiments before they are completed, and we have fully made up our minds as to the lessons to be learnt from them. There were, however, reasons why an exception seemed desirable in the case of our ensilage experiments. We could at any rate supply sufficient information to enable practical farmers to draw their own conclusions from the evidence brought before them. Any conclusions so put forward, however, should be accepted as possibiy subject to modification as the investigation proceeds.

Although many careful experiments are carried out on parts of the farm at Rothamsted without regard to cost, on other parts the object is to make a profit just as much as on any other farm. The dairy is an ordinary working dairy, intended to produce milk as cheaply as possible. A contract is generally made to furnish so many gallons of milk per day for a year, and it may be mentioned that for the past year the contract has been 17d., 21d., and $22 d$. for 17 pints delivered at a railway station in London. Within certain limits, the quantity contracted for must be delivered. If more is produced it must be got rid of some other way; and if there is a deficiency the only alternative is to purchase more cows.

In addition to the cows, there are stock of all ages, bred on the farm, and about 40 Irish oxen are generally purchased in the autumn to consume the rough grass left by the cows. The land is mixed arable and pasture, about equally divided. Much of the pasture is young, and that which is old is not good. Sheep's fescue and-Agrostis prevail, while white clover and the better grasses can only be obtained by high animal manuring. For six months of the year the stock are out in the fields, while during the other six months other food must be provided for them. A certain amount of succulent as well as dry food is therefore required. For the former, mangels grown on the 
farm, are generally depended upon; and for the latter, hay and straw, with a certain amount of purchased food.

Under these circumstances, which are as ordinary and commonplace as can well be imagined-and although milk only is sent to London, it would be the same if butter were made-the question to consider is: What benefit will be derived from the use of silage?

Each cow in milk requires about 7 tons of mangels during the 6 months, say, 60 cows $\times 7$............. 420 tons

100 head of other stock; each $3 \frac{1}{2}$ tons mangels or swedes 350 tons

$$
\text { Total ................. } 770 \text { tons }
$$

Estimating the dry matter in the roots to average 12 per cent., the 770 tons will give about $92 \frac{1}{2}$ tons of dry substance of food.

Ten tons of fresh cut grass, clover, or tares-equal to nearly $2 \frac{1}{2}$ tons of hay per acre-may be considered a full yield, and about one-fifth of the fresh weight would be dry matter. There would, therefore, be required 462 tous of the fresh green produce, or the produce of about 46 acres, to yield the same amount of dry matter as in the 770 tons of roots.

The question next arises-What crops should be grown for ensilage purposes? Should some of the corn crops be cut in the green state? should less roots be grown? or should clover, or pasture grass, be put into the silo?

With regard to the clover or pasture, there is the difficulty that a certain amount of hay is required for winter consumption, and if, in addition, a quantity of green grass were mown for the silo, less stock must be kept in the summer, which would be an objection. It is true that a rather better price is obtained for milk and butter in the winter; but, on the other hand, the cost of keep and attendance is much greater. Possibly it may be suggested that tares instead of roots should be grown; but the roots generally follow a second, and sometimes a third corn crop. Winter tares are an excellent crop, and of these a certain number of acres are always grown, but they are not to be compared with roots as a cleaning crop. In fact the substitution of a silage crop for roots, would be equivalent to giving up taking a barley crop after wheat.

If 25 tons of mangels were grown per acre, 28 acres would yield about $87 \cdot \frac{1}{2}$ tons dry substance of food, whilst of ensilaged crops it would require more than 40 acres to yield the same amount. The relative feeding values of these two descriptions of food form, therefore, a very serious matter for consideration. Of course, all the difficulties mentioned could be got over, if it were clearly shown that silage is a more profitable food. But without roots the land cannot 
be cleaned, unless by means of summer fallow, which is out of the question; and that land should be fairly clean is, certainly, an essential point in successful arable farming.

Practical farmers will thus see that there are difficulties, which are by no means fanciful, in the way of an extended adoption of ensilage; and that, notwithstanding all that has been said in favour of the process, there is a simplicity, and economy, in feeding off clover on the land, and the summer feeding of grass, which it will not be easy to supersede. Some may even go so far as to say: "I don't care how good silage may be as a food, I cannot see my way to adopt it, for I must grow roots." Others may say, "It ought to be a very good food indeed for me to use it, for it has a most disagreeable smell, which pervades the whole farm." The general view will probably be that some further information, derived from carefully conducted experiments, is very desirable.

\section{2.-The Construction, and the Filling, of the Silos.}

In May (1884), the ground was excavated, and the building of the silos, of which there are two, was commenced. Each measured 15 feet by 13 feet 10 inches; the depth being 22 feet, 17 feet below the surface of the ground, and 5 feet above it. The silos are built of brick and cement, and are, in fact, water-tight tanks, with a corrugated iron roof over them. Each silo is calculated to hold from 100 to 120 tons of compressed silage, and it was intended to fill one with red clover, and the other with meadow-grass and oats; but as the oats advanced rather beyond the point which was considered desirable for the purpose, this part of the experiment was postponed until another year.

The first crop of red clover-which was pure clover without rye grass-was a very fine one. There was no rain during the filling of the silo, although, owing to the delay caused by the weighing and sampling, the operation extended from June 23 to June 30 . 'The operations were as follows : every cart, as it came from the field, after passing over the weigh-bridge, was brought alongside the silo, and the clover was then passed through a chaff-cutter driven by steam; a sample of the chaff being taken from every load. Of the first crop, 98 tons were weighed in, several men and boys being employed within the silo to spread the chaff evenly, and tread it down. The material was first covered with boards fitting tolerably close, and then pressure was applied by means of hard Staffordshire bricks, weighing from 9 lbs. to $10 \mathrm{lbs}$. each. The pressure per square foot amounted to about $90 \mathrm{lbs}$.

At the end of August the boards were removed, and about 21 tons of a second crop of clover were weighed, chaffed, put in, and sampled. 
After the pressure had been again applied the material did not reach within 4 feet of the top. The contents then measured 3706 cubic feet. The silage of the upper 4 feet weighed $45 \frac{1}{2} \mathrm{lbs}$, and that of the lower 4 feet, $59 \frac{1}{2}$ lbs. per cubic foot, giving an average weight of 5:3.6 lbs. per cubic foot.

The second silo was filled in exactly the same way as the first, the meadow-grass with which it was filled being taken from four different fields. It will be evident that any information regarding the cost of filling the silo would of no value, as accuracy, and not economy, was the main object to be attained; and the operations are so simple that any practical farmer can form his own estimate on the subject. It must, however, be borne in mind, that in carrying fresh cut crops, four or five times as much weight has to be carted as would be the case if the crop were made into hay. Roughly speaking, 4 tons of fresh cut clover will make 1 ton of hay; so in all movements of the crop, either in or out of the silo, calculation for the extra amount of labour must be made accordingly.

\section{3.-Qdantity and Composttion of the Herbage put into the Silos, aNd OF THE Silage taken oUt.}

\section{Silo No. 1.}

Table I (p. 11) shows-the dates of filling Silo No. 1, the number of loads, the fresh weights of the clover as put in, the percentages of dry matter, ash, and nitrogen, in it, and the actual quantities of dry matter, ash, and nitrogen, put in.

Table II (p. 12) summarises the quantities of fresh clover, and of its various constituents, put into the silo; and it also shows-the quantities of silage, and of its various constituents, taken out; the actual loss of the various constituents; the percentage loss of each constituent, reckoning the total of each as 100 ; and the percentage loss of each constituent, reckoned on the total Fresh $=100$.

We have thought it desirable that these results should be given as fully as possible, in order that those who will take the trouble to examine them, may form their own conclusions respecting them. This is especially desirable, as upon one very important point, namely the loss of constituents which occurs in the silo, we, and probably most of those who are interested in what may be called the chemistry of ensilage, have formed our opinions mainly on results which have been published by German or French chemists.

It would appear to be a very simple thing to estimate the loss which takes place in a silo. It may be said-"You have only carefully to weigh everything that goes in, and everything that comes out, and it is done." It will be seen, however, that a good deal more 


\section{First and Second Crop Red Clover.}

TABle I.-Quantity and Composition of the Herbage put into Silo No. I.

\begin{tabular}{|c|c|c|c|c|c|c|c|c|c|}
\hline \multirow[b]{2}{*}{ Field. } & \multirow[b]{2}{*}{$\begin{array}{l}\text { When } \\
\text { put in. }\end{array}$} & \multirow{2}{*}{$\begin{array}{l}\text { No. of } \\
\text { Loads. }\end{array}$} & \multirow{2}{*}{$\begin{array}{c}\text { Fresh } \\
\text { Weight. }\end{array}$} & \multicolumn{3}{|c|}{ Percentage composition. } & \multicolumn{3}{|c|}{ Total weight. } \\
\hline & & & & $\begin{array}{c}\text { Dry } \\
\text { matter. }\end{array}$ & $\begin{array}{l}\text { Ash } \\
\text { in dry } \\
\text { matter. }\end{array}$ & $\begin{array}{l}\text { Nitrogen } \\
\text { in dry } \\
\text { matter. }\end{array}$ & $\begin{array}{c}\text { Dry } \\
\text { matier. }\end{array}$ & Ash. & Nitrogen. \\
\hline \multicolumn{10}{|c|}{ First Crop Clover. } \\
\hline Thirty acres... & $\begin{array}{cc}1884 . \\
\text { June } & 23 \\
, & 23 \\
" & 23 \\
, & 24 \\
, & 24 \\
, & 28\end{array}$ & $\begin{array}{r}20 \\
20 \\
5 \\
15 \\
14 \\
21\end{array}$ & $\begin{array}{r}\text { lbs. } \\
34,776 \\
39,035 \\
8,827 \\
24,462 \\
25,654 \\
34,965\end{array}$ & $\begin{array}{c}\text { Per cent } \\
16 \cdot 35 \\
16 \cdot 66 \\
19 \cdot 99 \\
18 \cdot 40 \\
19 \cdot 26 \\
23 \cdot 02\end{array}$ & $\begin{array}{c}\text { Per cent. } \\
10 \cdot 80 \\
11.80 \\
9 \cdot 68 \\
10 \cdot 72 \\
10.92 \\
10 \cdot 28\end{array}$ & $\begin{array}{c}\text { Per cent. } \\
2 \cdot 942 \\
2 \cdot 866 \\
2 \cdot 781 \\
2 \cdot 920 \\
2 \cdot 793 \\
2 \cdot 578\end{array}$ & $\begin{array}{l}\text { lbs. } \\
5,686 \\
6,503 \\
1,765 \\
4,501 \\
4,941 \\
8,049\end{array}$ & $\begin{array}{r}\text { lbs. } \\
614 \\
767 \\
171 \\
483 \\
540 \\
827\end{array}$ & $\begin{array}{r}\text { 1bs. } \\
167 \cdot 3 \\
186 \cdot 4 \\
49 \cdot 1 \\
131 \cdot 4 \\
138 \cdot 0 \\
207 \cdot 5\end{array}$ \\
\hline \multirow[t]{2}{*}{ Geescroft } & $\begin{array}{r}\text { June } 28 \\
28-30 \\
, \quad 30\end{array}$ & $\begin{array}{r}9 \\
15 \\
9\end{array}$ & $\begin{array}{l}12,628 \\
23,670 \\
13,677\end{array}$ & $\begin{array}{l}24 \cdot 07 \\
21 \cdot 32 \\
22 \cdot 83\end{array}$ & $\begin{array}{l}9 \cdot 64 \\
8 \cdot 98 \\
8 \cdot 87\end{array}$ & $\begin{array}{l}2 \cdot 423 \\
2 \cdot 382 \\
2 \cdot 385\end{array}$ & $\begin{array}{l}3,040 \\
5,046 \\
3,122\end{array}$ & $\begin{array}{l}293 \\
451 \\
277\end{array}$ & $\begin{array}{r}73 \cdot 7 \\
120 \cdot 2 \\
74 \cdot 5\end{array}$ \\
\hline & Total ... & 128 & 217,694 & ... & $\ldots$ & ... & 42,653 & 4,423 & $1148 \cdot 1$ \\
\hline
\end{tabular}

Second Crop Clover.

\begin{tabular}{|c|c|c|c|c|c|c|c|c|c|}
\hline Geescroft ....... & $\begin{array}{cc}\text { Aug. } & 25 \\
\text {, } & 25 \\
\text { " } & 26 \\
\text { " } & 26 \\
\text { " } & 26 \\
\text { ", } & 26 \\
\text { " } & 26\end{array}$ & $\begin{array}{l}4 \\
2 \\
8 \\
3 \\
4 \\
4 \\
3 \\
6\end{array}$ & $\begin{array}{r}6,950 \\
3,590 \\
12,831 \\
5,088 \\
5,483 \\
4,786 \\
9,032\end{array}$ & $\begin{array}{l}19 \cdot 13 \\
22 \cdot 66 \\
17 \cdot 10 \\
17 \cdot 92 \\
18 \cdot 56 \\
18 \cdot 72 \\
21 \cdot 90\end{array}$ & $\begin{array}{r}8 \cdot 61 \\
8 \cdot 92 \\
10 \cdot 45 \\
10 \cdot 15 \\
8 \cdot 45 \\
9 \cdot 22 \\
9 \cdot 15\end{array}$ & $\begin{array}{l}2 \cdot 616 \\
2 \cdot 704 \\
2 \cdot 688 \\
2 \cdot 668 \\
2 \cdot 502 \\
2 \cdot 623 \\
2 \cdot 524\end{array}$ & $\begin{array}{r}1,330 \\
813 \\
2,194 \\
912 \\
1,018 \\
896 \\
1,978\end{array}$ & $\begin{array}{r}115 \\
73 \\
229 \\
93 \\
86 \\
83 \\
181\end{array}$ & $\begin{array}{l}34 \cdot 8 \\
22 \cdot 0 \\
59 \cdot 0 \\
24 \cdot 3 \\
25 \cdot 5 \\
23 \cdot 5 \\
49 \cdot 9\end{array}$ \\
\hline \multirow[t]{2}{*}{ Weighed off ............. } & $\begin{array}{c}\text { Total .... } \\
\ldots\end{array}$ & $\begin{array}{r}30 \\
1\end{array}$ & $\begin{array}{r}47,760 \\
1,136\end{array}$ & $(19 \cdot 43)$ & $(\ddot{9} \cdot 28)$ & $(2 \ddot{6} 18)$ & $\begin{array}{r}9,141 \\
221\end{array}$ & $\begin{array}{r}860 \\
21\end{array}$ & $\begin{array}{r}239 \cdot 0 \\
5 \cdot 8\end{array}$ \\
\hline & Total .... & 29 & 46,624 & $\ldots$ & $\ldots$ & ... & 8,920 & 839 & $233 \cdot 2$ \\
\hline
\end{tabular}

Summary.

\begin{tabular}{|c|c|c|c|c|c|c|c|c|c|}
\hline \multirow[t]{3}{*}{$\begin{array}{l}\text { First crop clover...... } \\
\text { Second crop clover.. }\end{array}$} & $\ldots$ & $\begin{array}{r}128 \\
29\end{array}$ & $\begin{array}{r}217,694 \\
46,624\end{array}$ & $\ldots$ & $\ldots$ & $\ldots$ & $\begin{array}{r}42,653 \\
8,920\end{array}$ & $\begin{array}{r}4,423 \\
839\end{array}$ & $\begin{array}{r}1148 \cdot 1 \\
233 \cdot 2\end{array}$ \\
\hline & Total .... & 157 & 264,318 & $\ldots$ & $\ldots$ & $\ldots$ & 51,573 & 5,262 & $1381 \cdot 3$ \\
\hline & \multicolumn{2}{|c|}{ Tons, cwts. } & 1180 & $\ldots$ & $\ldots$ & $\ldots$ & $23 \quad 0 \frac{1}{2}$ & 27 & $\begin{array}{ll}0 & 12 \frac{1}{4}\end{array}$ \\
\hline
\end{tabular}

than this is required. So far as regards the total loss we have no difficulty. We weighed in 118 tons, and weighed out $88 \frac{3}{4}$ tons, thus showing a loss of $29 \frac{1}{4}$ tons. But the results further show that, of this loss, more than 28 tons consisted of water, and only about $1 \frac{1}{6}$ ton of dry or solid substance; the total loss of dry substance amounting to about 5 per cent. of that put in. It may be mentioned that this is very nearly the same amount of loss as that which we found had taken place in a large rick of about 40 tons of hay, after standing two years.

Careful experiments have been made in Germany, by Weiske and 
TABLE II.-Quantity and Composition-of the Herbage put into the Silo No. 1 ; of the Silage taken out; and actual, and Percentage, Loss of Constituents in the Silo.

\begin{tabular}{|c|c|c|c|c|c|c|c|c|}
\hline $\begin{array}{l}\text { Authority } \\
\text { for } \\
\text { Analyses. }\end{array}$ & Fresh. & $\begin{array}{c}\text { Dry } \\
\text { Matter. }\end{array}$ & Ash. & $\begin{array}{l}\text { Nitro- } \\
\text { gen. }\end{array}$ & Organic. & $\begin{array}{c}\text { Crude } \\
\text { Nitrogenous } \\
\text { Substance } \\
=\mathrm{N} \times 6.25 \text {. }\end{array}$ & $\begin{array}{c}\text { Crude } \\
\text { Non- } \\
\text { Nitrogenous } \\
\text { Substance. }\end{array}$ & Wates. \\
\hline
\end{tabular}

Herbage as put into the Silo No. 1.

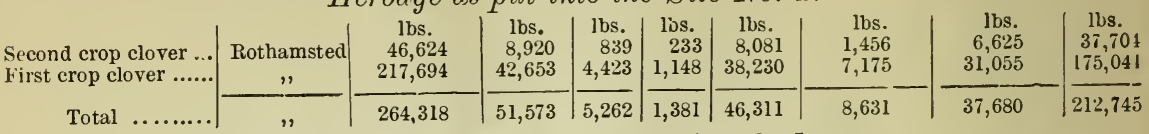

Silage taken out of the Silo No. 1.

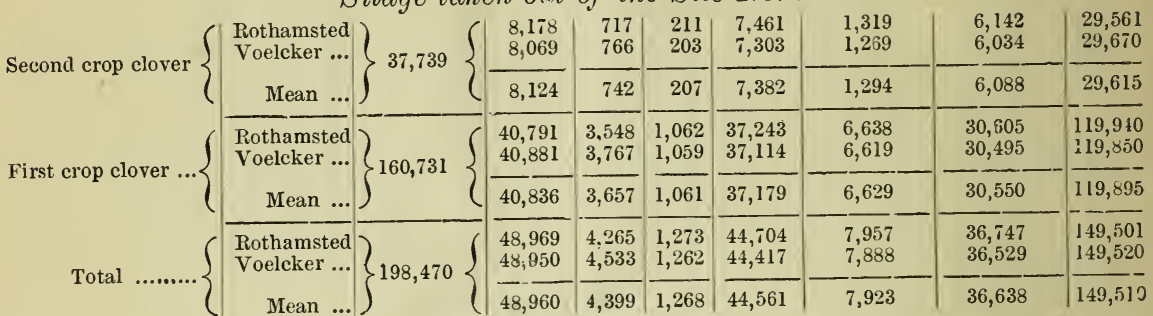
Actual Loss of Constituents.

Second crop clover $\left\{\begin{array}{l}\text { Rothamsted } \\ \text { Voeteker ... }\end{array}\right\} \quad 8,885\left\{\begin{array}{r|r|r|r|r|r|r|r|}742 & 122 & 22 & 620 & 137 & 483 & 8,143 \\ 851 & 73 & 30 & 778 & 187 & 59 \mathrm{I} \\ \hline\end{array}\right.$

\begin{tabular}{|c|c|c|c|c|c|c|c|c|c|}
\hline Second crop clover & \multicolumn{3}{|c|}{ Voelcker $\cdots\} 8,885\}$} & & & & & & \\
\hline \multirow{3}{*}{ First crop cluver } & Mean ... & & 796 & 97 & 26 & 699 & 162 & 537 & 8,089 \\
\hline & $\begin{array}{l}\text { Rothamsted } \\
\text { Voelcker ... }\end{array}$ & 56,963 & $\begin{array}{l}1,862 \\
1,772\end{array}$ & $\begin{array}{l}875 \\
656\end{array}$ & $\begin{array}{l}86 \\
89\end{array}$ & $\begin{array}{r}987 \\
1,116\end{array}$ & $\begin{array}{l}537 \\
556\end{array}$ & $\begin{array}{l}450 \\
560\end{array}$ & $\begin{array}{l}55,101 \\
55,191\end{array}$ \\
\hline & Mean ... & & 1,817 & 766 & 87 & 1,051 & 546 & 505 & 55,146 \\
\hline \multirow{2}{*}{ Total } & $\begin{array}{l}\text { Rothamsted } \\
\text { Voelcker ... }\end{array}$ & \multirow{2}{*}{65,848} & $\begin{array}{l}2,604 \\
2,623\end{array}$ & $\begin{array}{l}997 \\
729\end{array}$ & $\begin{array}{l}103 \\
119\end{array}$ & $\begin{array}{l}1,607 \\
1,894\end{array}$ & $\begin{array}{l}674 \\
743\end{array}$ & $\begin{array}{r}933 \\
1,151\end{array}$ & $\begin{array}{l}63,244 \\
63,225\end{array}$ \\
\hline & Mean . & & 2,613 & 863 & 113 & 1,750 & 708 & $1,04^{*}$ & 63,235 \\
\hline
\end{tabular}

Per Cent. Loss - Total of each Constituent $=100$.

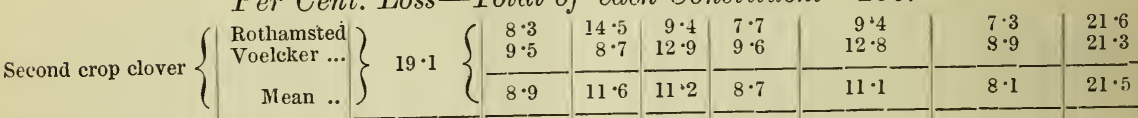

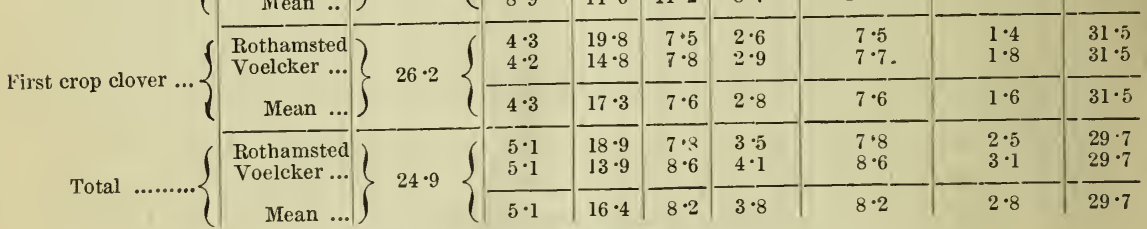
Per Cent. Loss-Total Fresh $=100$.

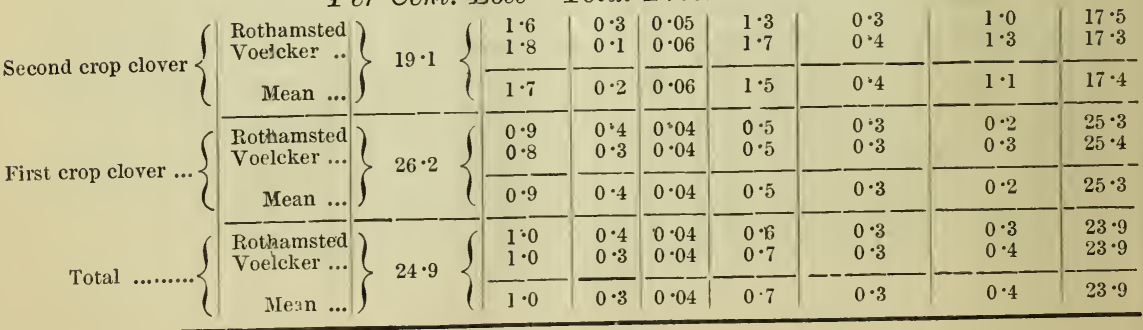


Schulze, on the changes and losses in ensilaging; and as their results are familiar to all those who have studied the chemistry of ensilage, we propose merely to refer to them so far as to point out that with lupines, maize, and lucerne, the loss during fermentation amounted to between 22 and 36 per cent. of the dry matter. In some of the experiments one-third or more of some of the food-constituents contained in the green crops put in, was destroyed, while another portion was reduced in value. The experiments were made in tight casks, and in some cases the filling in and the putting on of the pressure were done at once; whilst in others the filling was extended to six or seven days. The latter was about the time occupied in the process in our own experiments.

In the German experiments the loss of water was very small, but there was a considerable loss of mineral matter. It has been generally held that, as in the fermentation of vegetable substances, which contain both organic and mineral matter, the destruction of the former necessarily increases the percentage of the latter, the difference between the amount of mineral matter in the fresh crop put into the silo and that in the silage taken out, would, in some degree, be a measure of the loss of organic matter during fermentation, and also be some check on the accuracy of the work. Weiske and Schulze point out, however, that owing to the sand, and other adventitious mineral matters, with which bulks of herbage from the field are always contaminated, the difference in the amounts cannot be relied upon as a basis of calculation. Our own results fully confirm this view. Indeed, they show a loss, and not a gain, of mineral matter in the silage, as compared with that in the clover put in. It is true that our loss of dry substance would only amount to 1 per cent. of the fresh herbage, and the loss of mineral matter to about one-third of 1 per cent.; but small as this loss appears to be, according to one set of analyses it amounts to $729 \mathrm{lbs}$., and to the other to $1000 \mathrm{lbs}$. in the total quantity of mineral substances contained in the 118 tons of clover that were put into the silo.

The complete explanation of this loss is not very obvious, It may be pointed out, however, that of the 16 samples of clover which were taken as the crop was chaffed and put into the silo, the variations in the percentage of ash are very great; the lowest being a little below $8 \frac{1}{2}$, and the highest nearly 12 per cent. of the dry substance.

The depth of the silage in the pit was between 17 and 18 feet; and its removal for feeding purposes was a daily operation extending orer three months. It was taken out in four layers, each of 4 to 5 feet in depth. From each layer five, six, or more samples were taken for analysis. A quantity of 1000 lbs., or more, was weighed, and rapidly mixed on an asphalte floor, so as to avoid loss by evaporation as much 
as possible; and from this samples were taken. To ascertain the range of loss by evaporation in such an operation several experiments were made, of which the following is an example:-

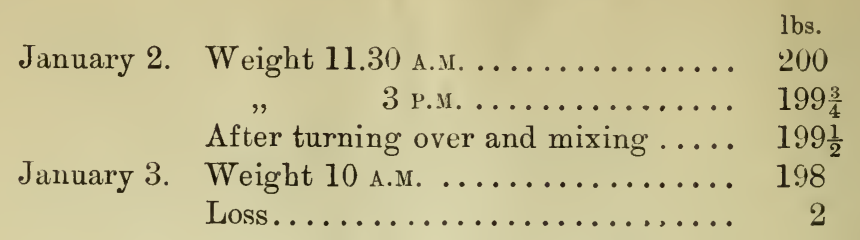

On a very windy day the loss amounted to $2 \frac{1}{2}$ per cent., and on a still, damp day, it was less than $\frac{1}{4}$ per cent. On the 25 th April, the weighing machine was taken into the silo, and a block of silage, about 3 feet by 2 feet by 3 feet deep, was cut out and immediately weighed in baskets, when the weight was found to be $814 \mathrm{lbs}$. It was then taken to the mixing floor, where it was turned over three times, and samples were taken from it. At the end of an hour the silage was again weighed, and the loss was found to be not quite $1 \frac{3}{4}$ per cent. It was noticed that the floor, although previously quite dry, had become wet. It may also be mentioned that the weather was much warmer when this experiment was carried out, and that the silage was taken from the second silo, the first having been emptied some weeks previously.

It should be added that the silos, which, as already explained, were built of brick and cement, were filled very shortly after they were finished. This may to a certain extent have been a soarce of loss, as a good deal of the floor rested upon the chalk, which would carry away water very rapidly if there were any crack in the cement. It is quite possible, therefore, that some loss by drainage did take place. The late Dr. Voelcker gave the composition of the drainage from a silo as 90 per cent. of water, and 10 per cent. solid matter, of which more than one-third was mineral.

It seems somewhat difficult to suppose that the very large loss of water in the silo was wholly due to evaporation, when the loss of organic matter, by fermentation, was so small. But it is to be observed that the lower layers were removed more slowly than the others, so that the cut surfaces were longer exposed: whilst, as a matter of fact, the silage was drier towards the bottom. On the other hand, some drainage was observed soon after the filling and the application of the pressure, so that some at any rate of the loss was due to drainage. If we were to assume that drainage had taken place sufficient to carry off the whole of the apparent loss of mineralsamounting to $863 \mathrm{lbs}$.- in a solution of the strength of the liquid which was pressed out of a silo, and was analysed by the late Professor Voelcker, the loss 0 : water by drainage would be 8 per cent., and by 
evaporation 17 per cent.; but the actual loss by diainage was probably less than here supposed.

It is satisfactory to kncw that the Council of the Bath and West of England Society bave voted a sum of money for the purpose of investigating the loss of nutritive substances which takes place during the fermentation of green crops in a silo; and it is to be hoped that the experiments will be carried out with the necessary care. It is evident that, until this important matter has been thoroughly sifted, all estinates in regard to the economy of ensilaging, as compared with the ordinary operations of the farm, are little better than guess-work.

\section{Silo No. 2.}

Silo No. 2 was similar in all respects to Silo No. 1, as already described; and was only divided from it by a 9-inch wall. From June 25 to July 2 (1884), about $45 \frac{1}{2}$ tons of first-crop meadow-grass, from four different fields, were first put in. The whole of the grass was of fairly good quality: but that from the second field was much the ripest. It was intended to follow with winter oats; but the hot, weather brought the crop too forward to be suitable for silage; so the full pressure was applied.

The silo was opened on August 23, when, from that date to August 26 , about $30 \frac{1}{2}$ tons of second-crop red clover were put in.

In the middle of October the weights were again removed, and about $i \frac{1}{2}$ tons of second-crop meadow-grass were put in. Part of this grass was from land which had already been mown once; and the rest was from a field which had been fed, and consisted chiefly of the portions which, having grown too strong, had been left by the stock.

As in the case of Silo No. 1, all the crops were chaffed, and the naterial was evenly spread and well trodden down, as it was put in.

Table III (p. 16) gives the fresh weights of each lot of herbage put into the silo; also the percentages, and the actual quantities, of dry watter, mineral matter, and nitrogen, which each contained.

Table IV (p. 17) summarises the amounts of fresh herbage, and its various constituents, put into the silo, and gives the amounts of silage, and of its various constituents taken out. It also shows the actual loss of each of the constituents in the silo, the loss per 100 of each, and the loss of each per 100 of fresh herbage put in.

Comparison of the results given in Table III, with those formerly given in Table I, relating to the herbage put into Silo No. 1, will show that whilst the dry matter in the first-crop clover put into Silo No. 1 ranged from under 17 to 24 per cent., and that of the secondcrop clover from over 17 to under 23 per cent., the dry matter of the first-crop meadow-grass put into Silo No. 2 ranged from $24 \frac{3}{4}$ to nearly 32 per cent., that of the second-crop grass was more than 38 per cent., 
First and Second Crop Meadow-Grass, and Second Crop Clover. TABLE III.-Quantity and Composition of the Herbage put into Silo No. 2.

\begin{tabular}{|c|c|c|c|c|c|c|c|c|c|}
\hline \multirow[b]{2}{*}{ Field. } & \multirow{2}{*}{$\begin{array}{l}\text { When } \\
\text { put in. }\end{array}$} & \multirow{2}{*}{$\begin{array}{l}\text { No. of } \\
\text { Loads. }\end{array}$} & \multirow{2}{*}{$\begin{array}{c}\text { Fresh } \\
\text { Weight. }\end{array}$} & \multicolumn{3}{|c|}{ Percentage composition. } & \multicolumn{3}{|c|}{ Total weight. } \\
\hline & & & & $\begin{array}{c}\text { Dry } \\
\text { matter. }\end{array}$ & $\begin{array}{l}\text { Ash in } \\
\text { dry } \\
\text { matter. }\end{array}$ & $\begin{array}{l}\text { Nitrogen } \\
\text { in dry } \\
\text { matter. }\end{array}$ & $\begin{array}{c}\text { Dry } \\
\text { matter. }\end{array}$ & Ash. & $\begin{array}{l}\text { Nitro- } \\
\text { gen. }\end{array}$ \\
\hline
\end{tabular}

First Crop Meaduw-Grass.

\begin{tabular}{|c|c|c|c|c|c|c|c|c|c|}
\hline $\begin{array}{l}\text { Broadbalk and Appletree } \\
\text { Dr. Gilbert's meadow...... } \\
\text { Park and Grass-wick...... } \\
\text { Park and Lodge Meadow }\end{array}$ & \begin{tabular}{rr}
\multicolumn{2}{c}{1884.} \\
June & $25-26$ \\
, & $25-26$ \\
Jüly & 26 \\
& 2
\end{tabular} & $\begin{array}{l}29 \\
12 \\
11 \\
20\end{array}$ & $\begin{array}{l}\text { lbs. } \\
40,802 \\
19,609 \\
13,639 \\
27,930\end{array}$ & $\begin{array}{c}\text { Per cent. } \\
24 \cdot 72 \\
31 \cdot 86 \\
27 \cdot 30 \\
26 \cdot 66\end{array}$ & $\begin{array}{l}\text { Per cent. } \\
8 \cdot 47 \\
7 \cdot 67 \\
7 \cdot 44 \\
8 \cdot 14\end{array}$ & $\begin{array}{c}\text { Per cent. } \\
1 \cdot 685 \\
1 \cdot 340 \\
1 \cdot 628 \\
1 \cdot 670\end{array}$ & \begin{tabular}{r}
\multicolumn{1}{c}{ lbs. } \\
10,086 \\
6,247 \\
3,723 \\
7,446
\end{tabular} & $\begin{array}{l}\text { lbs. } \\
854 \\
479 \\
277 \\
606\end{array}$ & $\begin{array}{l}\text { lbs. } \\
169 \cdot 9 \\
83 \cdot 7 \\
60 \cdot 6 \\
124 \cdot 3\end{array}$ \\
\hline & Total ....... & 72 & 101,980 & $\ldots$ & $\ldots$ & $\ldots$ & 27,502 & 2,216 & $438 \cdot 5$ \\
\hline
\end{tabular}

Second Crop Clover.

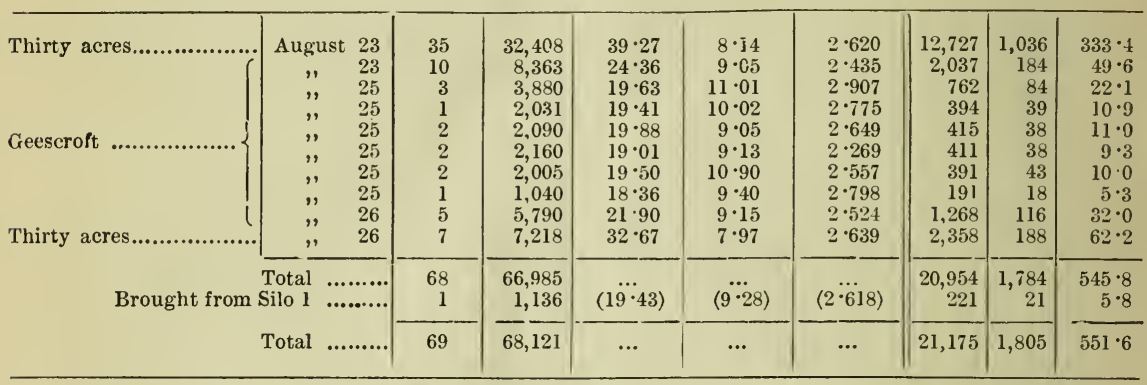

Second Crop Meadow-Grass.

\begin{tabular}{|c|c|c|c|c|c|c|c|c|c|}
\hline Park and Park Field ..... & October 17 & 17 & 14,858 & $38 \cdot 13$ & $9 \cdot 04$ & $1 \cdot 890$ & 5,665 & 512 & $107 \cdot 0$ \\
\hline
\end{tabular}

\section{Summary.}

\begin{tabular}{|c|c|c|c|c|c|c|c|c|}
\hline 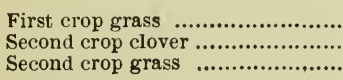 & $\begin{array}{l}72 \\
69 \\
17\end{array}$ & $\begin{array}{r}101,980 \\
68,121 \\
14,858\end{array}$ & $\begin{array}{l}\cdots \\
\cdots \\
\cdots\end{array}$ & $\begin{array}{l}\cdots \\
\cdots\end{array}$ & $\begin{array}{l}\cdots \\
\cdots \\
\cdots\end{array}$ & $\begin{array}{r}27,502 \\
21,175 \\
5,665\end{array}$ & $\begin{array}{r}2,216 \\
1,805 \\
512\end{array}$ & $\begin{array}{l}438 \cdot 5 \\
551 \cdot 6 \\
107 \cdot 0\end{array}$ \\
\hline Total ............ & 158 & 184,959 & $\ldots$ & $\ldots$ & $\ldots$ & 54,342 & 4,533 & $1,097 \cdot 1$ \\
\hline & , cwt... & $82 \quad 11 \frac{1}{2}$ & ... & $\ldots$ & $\ldots$ & $24 \quad 5 \frac{3}{2}$ & $\left|\begin{array}{ll}2 & 0 \frac{1}{2}\end{array}\right|$ & $\begin{array}{ll}0 & 93\end{array}$ \\
\hline
\end{tabular}

and that of the second-crop clover ranged from over 18 to over 39 per cent. Indeed, more than two-thirds of the clover put into the Silo No. 2 averaged nearly 36 per cent. dry matter. It is thus seen that the herbage put into Silo No. 2 contained a very much less proportion of water than that put into Silo No. 1. It was, in fact, upon the whole, riper, and doubtless more woody, especially so far as the meadow-grass was concerned. 
TABLE IV.-Quantity and Composition of the Herbage put into Silo No.2; of the Silage taken out; and Actual and Percentage Loss of Constituents in the Silo.

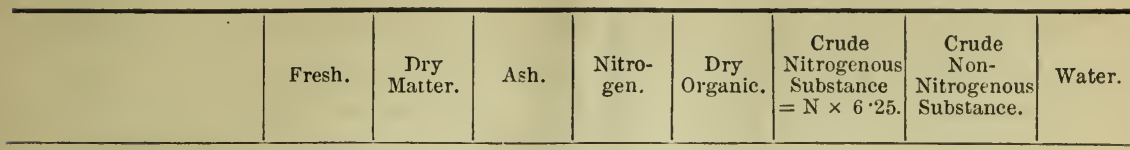

Herbage as put into the Silo.

\begin{tabular}{|c|c|c|c|c|c|c|c|c|}
\hline $\begin{array}{l}\text { Second crop grass............. } \\
\text { Second crop clover ......... } \\
\text { First crop grass............... }\end{array}$ & $\begin{array}{c}\text { Jbs. } \\
14,858 \\
68,121 \\
101,980\end{array}$ & $\begin{array}{r}\text { lbs. } \\
5,665 \\
21,175 \\
27,502\end{array}$ & $\begin{array}{r}1 \mathrm{bs} . \\
512 \\
1,805 \\
2,216\end{array}$ & $\begin{array}{l}\text { lbs. } \\
107 \\
552 \\
438\end{array}$ & $\begin{array}{c}\text { lbs. } \\
5,153 \\
19,370 \\
25,2 \succ 6\end{array}$ & $\begin{array}{r}\text { lbs. } \\
669 \\
3,450 \\
2,738\end{array}$ & $\begin{array}{r}1 \mathrm{bs} . \\
4,484 \\
15,920 \\
22,548\end{array}$ & $\begin{array}{l}\text { lbs. } \\
9,193 \\
46,946 \\
74,478\end{array}$ \\
\hline Total & 184,959 & 54,342 & 4,533 & 1,097 & 49,809 & 6,857 & 42,952 & 130,617 \\
\hline
\end{tabular}

Silage taken out of the Silo.

\begin{tabular}{r|r|r|r|r|r|r|r|r}
\hline Second crop grass........... & 14,473 & $5,, 68$ & 525 & 91 & 4,543 & 568 & 3,975 & 9,405 \\
Second crop clover ......... & 65,670 & 20,651 & 1,809 & 551 & 18.842 & 3.444 & 15,398 & 45,019 \\
First crup grass.............. & 90,798 & 23,361 & 2,086 & 369 & 21,275 & 2,306 & 18,969 & $6 \overline{7}, 437$ \\
\hline Total $\ldots . . . . . .$. & 170,941 & 49,080 & 4,420 & 1,011 & 44,660 & 6,318 & 38,342 & 121,861 \\
\hline
\end{tabular}

Actual. Loss of Constituents.

\begin{tabular}{r|r|r|r|r|r|r|r|r}
\hline Secund crop grass.......... & 385 & 597 & +13 & 16 & 610 & 101 & 509 & +212 \\
Ser.ond crop clover ........ & 2,451 & 524 & +4 & 1 & 528 & 5 & 522 & 1,927 \\
First crop grass............. & 11,182 & 4,141 & 130 & 69 & 4,011 & 432 & 3,579 & 7,041 \\
\hline Total $\ldots . . . . . .$. & 14,018 & 5,262 & 113 & 86 & 5,149 & 539 & 4,610 & 8,756 \\
\hline
\end{tabular}

Loss per Cent.--Total of each Constituent $=100$.

\begin{tabular}{|c|c|c|c|c|c|c|c|c|}
\hline $\begin{array}{l}\text { Second crop grass .............. } \\
\text { Second crop clover } \ldots . \ldots \ldots . \\
\text { First crop grass............... }\end{array}$ & $\begin{array}{c}\text { Per cent. } \\
2 \cdot 6 \\
3 \cdot 6 \\
11 \cdot 0\end{array}$ & $\begin{array}{c}\text { Per cent. } \\
10 \cdot 5 \\
2 \cdot 5 \\
15 \cdot 1\end{array}$ & $\begin{array}{c}\text { Per cent. } \\
+2 \cdot 5 \\
+0 \cdot 2 \\
5 \cdot 9\end{array}$ & $\begin{array}{c}\text { Per cent. } \\
15 \cdot 1 \\
0.2 \\
15 \cdot 8\end{array}$ & $\begin{array}{c}\text { Per cent. } \\
11 \cdot 8 \\
2 \cdot 7 \\
15 \cdot 9\end{array}$ & $\begin{array}{c}\text { Per cent. } \\
15 \cdot 1 \\
0 \cdot 2 \\
15 \cdot 8\end{array}$ & $\begin{array}{c}\text { Per cent. } \\
11 \cdot 4 \\
3 \cdot 3 \\
15 \cdot 9\end{array}$ & $\begin{array}{c}\text { Per cent. } \\
+2 \cdot 3 \\
4 \cdot 1 \\
9 \cdot 5\end{array}$ \\
\hline Total .......... & $7 \cdot 6$ & $9 \cdot 7$ & $2 \cdot 5$ & $7 \cdot 8$ & $10 \cdot 3$ & $7 \cdot 8$ & $10 \cdot 7$ & $6 \cdot 7$ \\
\hline
\end{tabular}

Loss per Cent.-Total Fresh $=100$.

\begin{tabular}{|c|c|c|c|c|c|c|c|c|}
\hline $\begin{array}{l}\text { Second crop grass............ } \\
\text { Second crop clover ........ } \\
\text { First crop grass............. }\end{array}$ & $\begin{array}{r}2 \cdot 6 \\
3 \cdot 6 \\
11 \cdot 0\end{array}$ & $\begin{array}{l}4 \cdot 0 \\
0 \cdot 8 \\
4 \cdot 1\end{array}$ & $\begin{array}{c}+0.09 \\
+0.006 \\
0.1\end{array}$ & $\begin{array}{l}0 \cdot 11 \\
0 \cdot 001 \\
0 \cdot 07\end{array}$ & $\begin{array}{l}4 \cdot 1 \\
0 \cdot 8 \\
3 \cdot 9\end{array}$ & $\begin{array}{l}0.7 \\
0.009 \\
0.4\end{array}$ & $\begin{array}{l}3 \cdot 4 \\
0 \cdot 8 \\
3 \cdot 5\end{array}$ & $\begin{array}{r}+1 \cdot 4 \\
2 \cdot 8 \\
7 \cdot 0\end{array}$ \\
\hline Total ....... & $7 \cdot 6$ & $2 \cdot 3$ & $0 \cdot 06$ & 004 & $2 \cdot 8$ & $0 \cdot 3$ & $2 \cdot 5$ & $4 \cdot 7$ \\
\hline
\end{tabular}

The great difference in the composition of the various crops put into the silos renders it extremely difficult to determine with certainty the changes and the losses which take place in them. There is also considerable difficulty arising from the depth of the silage in the pits, and the necessity of taking it out in several separate layers, and occupying weeks, or it may be months, in the process. The experience gained 
this first year will probably enable us the better to guard against some of these possible sources of error in the futnre.

The columns of Table III (p. 16), giving the percentages of ash and of nitrogen in the dry matter of the herbage put into Silo No. 2, show that, whilst in the first crop of grass the ash varied from $7 \frac{1}{2}$ to $8 \frac{1}{2}$ per cent., and in the second crop of grass it was about 9 per cent., in the second crop of clover it varied from about 8 to about 11 per cent. of the dry matter. There is a still greater difference in the percentages of nitrogen in the dry matter of the two descriptions of herbage. Thus, whilst in the dry matter of the meadow-grass, the nitrogen ranged from 1.34 to 1.89 per cent., in that of the clover it ranged firom $2 \cdot 27$ to $2 \cdot 91$ per cent.

Turning now to Table IV (p. 17) it is seen that the proportion of water lost in the silo was comparatively small; both in the meadowgrass and in the clover. The loss was in fact much less than in Silo No. 1. The crops put into the Silo No. 2 contained, it is true, a much less proportion of water than those put into Silo No. 1. But the amount of loss by fermentation was much greater, and hence it would be supposed that the greater heat developed would have caused more evaporation. It would seem, therefore, as was supposed, that part of the greater loss of water in Silo No. 1 was due to drainage, and part to the length of time taken in using the silage, and the consequent long exposure of the cut surfaces. In the second crop of clover in Silo No. 2 the loss of water indicated is only $4 \cdot 1$ per cent., whilst in the second crop of clover in the Silo No. 1 it amounted to over 20 per cent. Further, it will be observed that there was an actual gain of water by the second crop of grass, which formed the top layer in Silo No. 2, it having doubt'ess absorbed watery vapour from the layers below it.

The table (IV) shows that the losses of dry substance, and of its several organic constituents, were much greater, both in the first crop of grass which was at the bottom of the silo, and in the second crop of grass which was at the top, than in the clover between them. Of the 21,175 lbs. dry substance in the clover put into the silo, there was a lass of only $524 \mathrm{lbs}$, , or of only 2.5 per cent.; whilst in the first crop grass below it there was a loss of $15 \cdot 1$ per cent., and in the second crop grass above it, a loss of 10.5 per cent. of the dry matter put in.

Of mineral matter, or ash, the figures show a gain in the second crop grass, and in the second crop clover, but a loss in the first crop grass. An examination of the ashes of the herbage put in, and of the silage taken out, clearly shows that, as before assumed, the irregularity is dependent on the variable amounts of adventitious mineral matter in the ashes.

Of the tota! nitrogen, the loss in the first crop of grass below the 
clover was 15.8 per cent., and in the second crop grass above the clover it was nearly the same, namely, $15 \cdot 1$ per cent.; whilst in the clover itself, between them, the percentage of nitrogen in which is so much higher, the loss of it was extremely small, amounting to less than a quarter of 1 per cent.

Thus, contrary to what might have been expected, the results indicate much more loss of dry matter, and of its several constituents, in the meadow-grass than in the clover. Further reference to the various changes and losses will be made when we come to consider the chemical composition of the herbage put in, and of the silage taken out of the silos. It is obvious that, so far as the results of these first experiments are to be relied upon, the losses of the foodconstituents of the crops are far less than in the German experiments before referred to.

\section{4.-The Chemical Composition of the Silage.}

Although a very large amount of analytical work has been executed in connection with our ensilage experiments, the data at present at command are insufficient to enable us to discuss at all adequately the changes, and the losses, which have taken place in the herbage put into the silo. Still, the results do bring to view some points of interest respecting which there can be little doubt.

Confining attention on the present occasion to Silo No. 1, it may be stated that, of the herbage put in, nine different mixed samples were made of the first-crop red-clover, and seven of the second-crop redclover, as chaffed and put into the silo. Each of these samples represents the number of loads, and the weight of herbage, as shown in Table I, page 11; and is a mixture of a given quantity taken from each individual load. Unfortunately, the pressure of other work in the Rothamsted Laboratory rendered it quite impossible to determine the composition of these mixed samples in the green, undried condition. Each was, however, carefully sun-and-air dried; and in each, the dry matter, the ash, and the total nitrogen, were determined at Rothamsted. In proportionally mixed samples, representing, respectively, the whole of the first crop, and the whole of the second crop, the amounts of total nitrogen, of albuminoid nitrogen, and of woody fibre, have also been determined. The analyses of these mixed samples are, however, incomplete, but we are able to give, further on, a general indication of their bearing.

The first crop of clover put into the silo formed a layer of silage of 13 feet 10 inches in depth; and the second crop clover above it a layer of 4 feet of silage.

This latter, the second crop clover-silage, was taken out in one layer 
to its full depth; and six samples were taken from it, namely-on December 13, 15, 18, and 30, 1884, and January 2 and 7,1885 . In each of these, the dry matter, the ash, and the total nitrogen, were determined at Rothamsted; and of three of them, namely, those taken on December 13, 18, and 30, more complete analyses were made by Dr. John A. Voelcker.

The first crop clover-silage was taken out in four layers, respectively of 4 feet 2 inches, 4 feet, 5 feet, and 8 inches, in depth. From the first layer five samples, namely, on January 14, 17, 20, 23, and 28, were taken; from the second layer five samples were taken, namely, on February 2, 6, 10, 17, and 19; from the third layer six samples were taken, namely, on March 6, 12, 14, 18, and 26, and April 4; and from the fourth layer five samples, namely, on March 10, 13, 17, and 20, and April 2. In each of these first crop cloversilage samples, the dry matter, the ash, and the total nitrogen, were, as before, determined at Rothamsted; and more complete analyses were made by Dr. John A. Voelcker, of the samples of January 17 and 23, of the first layer; of February 6 and 17 of the second layer; and of March 12 of the third layer. It was intended that another complete analysis of the silage of the third layer, and at least one of that of the fourth layer, should have been made, but this has not been accomplished.

Tables V and VI (pp. 21 and 22) give the results of the three complete analyses of the second-crop clover-silage, and of the five of the first-crop clover-silage ; and, in the lower part of each table, is given a summary showing, side by side with Dr. Voelcker's determinations of diry matter, ash, and nitrogen, those made at Rothamsted in the same samples. Table $V$ shows the percentage composition of the silage in the moist condition in which the samples were taken; and Table VI shows the percentage composition of the dry substance of the silage.

It will be seen that, upon the whole, Dr. Voelcker's and the Rothamsted determinations of dry matter, and of nitrogen, in the silage, agree very closely. Dr. Voelcker's determinations of mineral matter, or ash, are, however, always higher than those made at Rothamsted; the difference being probably due to the fact that, in the Rothamsted ashes, all visible adventitious matter was carefully picked out, whilst this was not done in the case of Dr. Voelcker's ashes.

It is frequently assumed that, although there is more or less loss of certain food-constituents in the conversion of succulent herbage into silage, yet this is more than compensated by the conversion of indigestible into digestible matter. The results at present at our command certainly do not seem to bear out this view. 


\section{Analyses of the Silage from Silo No. L; First and Segcond Crop Red Clover ;}

\section{Complete Analyses by Dr. J. A. Voelcker; Partial Analyses made at Rothamsted.}

Table V.-Per Cent. in Fresh Silage. Detailed Analyses of each Layer.

\begin{tabular}{|c|c|c|c|c|c|c|c|c|c|c|}
\hline \multirow{3}{*}{ Constituents. } & \multicolumn{4}{|c|}{ 2nd Crop Red Clover. } & \multicolumn{6}{|c|}{ 1st Crop Red Clover. } \\
\hline & \multicolumn{4}{|c|}{ Depth of Silage 4 feet. } & \multicolumn{2}{|c|}{$\begin{array}{l}\text { lst depth, } \\
4 \text { feet } 2 \text { inches. }\end{array}$} & \multicolumn{2}{|c|}{$\begin{array}{l}\text { 2nd depth, } \\
4 \text { feet. }\end{array}$} & \multirow{2}{*}{$\begin{array}{c}\text { 3rd } \\
\text { depth, } \\
5 \text { feet. } \\
\text { Sample 1 } \\
\text { taken } \\
\text { Mar. 12, } \\
1885 .\end{array}$} & \multirow{2}{*}{ Mean. } \\
\hline & $\begin{array}{c}\text { Sample } 1 \\
\text { taken } \\
\text { Dec. } 13 \text {, } \\
1884 .\end{array}$ & $\begin{array}{c}\text { Sample } 2 \\
\text { taken } \\
\text { Dec. } 18 \\
1884\end{array}$ & $\begin{array}{c}\text { Sample } 3 \\
\text { taken } \\
\text { Dec. } 30 \\
1884\end{array}$ & Mean. & $\begin{array}{c}\text { Sample } 1 \\
\text { taken } \\
\text { Jan. 17, } \\
1885 .\end{array}$ & $\begin{array}{c}\text { Sample } 2 \\
\text { taken } \\
\text { Jan. 23, } \\
1885 .\end{array}$ & $\begin{array}{c}\text { Sample ] } \\
\text { taken } \\
\text { Feb. 6, } \\
1885 .\end{array}$ & $\begin{array}{l}\text { Sample 2 } \\
\text { taken } \\
\text { Feb. 17, } \\
1885 .\end{array}$ & & \\
\hline Water........................ & $\begin{array}{l}\text { P. cent. } \\
78 \cdot 39\end{array}$ & $\begin{array}{c}\text { P. cent. } \\
79 \cdot 17\end{array}$ & $\begin{array}{c}\text { P. cent. } \\
78 \cdot 30\end{array}$ & $\begin{array}{c}\text { P. cent. } \\
78 \cdot 62\end{array}$ & $\begin{array}{c}\text { P. cent. } \\
76 \cdot 24\end{array}$ & $\begin{array}{c}\text { P. cent. } \\
76^{\circ} 49\end{array}$ & $\begin{array}{r}\text { P. cent. } \\
73 \cdot 84\end{array}$ & $\begin{array}{c}\text { P. cent. } \\
73.88\end{array}$ & $\begin{array}{r}\text { P. cent. } \\
73 \cdot 82\end{array}$ & $\begin{array}{r}\text { P. cent. } \\
: 4.85\end{array}$ \\
\hline $\begin{array}{l}\text { Soluble Albuminoids ...... } \\
\text { Insoluble Albuminoids ... }\end{array}$ & $\begin{array}{l}0 \cdot 12 \\
1 \cdot 94\end{array}$ & $\begin{array}{l}0 \cdot 44 \\
1 \cdot 75\end{array}$ & $\begin{array}{l}0 \cdot 49 \\
1 \cdot 69\end{array}$ & $\begin{array}{l}0 \cdot 35 \\
1 \cdot 79\end{array}$ & $\begin{array}{l}0 \cdot 31 \\
\mathrm{~J} \cdot 81\end{array}$ & $\begin{array}{l}0 \cdot 50 \\
1 \cdot 81\end{array}$ & $\begin{array}{l}0 \cdot 88 \\
1 \cdot 93\end{array}$ & $\begin{array}{l}0 \cdot 75 \\
1 \cdot 75\end{array}$ & $\begin{array}{l}0 \cdot 56 \\
2 \cdot 19\end{array}$ & $\begin{array}{l}0 \cdot 60 \\
1 \cdot 90\end{array}$ \\
\hline Total ... & $2 \cdot 06$ & $2 \cdot 19$ & $2 \cdot 18$ & $2 \cdot 14$ & $2 \cdot 12$ & $2 \cdot 31$ & $2 \cdot 81$ & $2 \cdot 50$ & $2 \cdot 75$ & $2 \cdot 50$ \\
\hline $\begin{array}{l}\text { Soluble Ash } \ldots . . . \ldots . \\
\text { Insuluble Ash . ...... }\end{array}$ & $\begin{array}{l}1 \cdot 28 \\
0 \cdot 76\end{array}$ & $\begin{array}{l}1 \cdot 37 \\
0 \cdot 64\end{array}$ & $\begin{array}{l}1 \cdot 28 \\
0 \cdot 75\end{array}$ & $\begin{array}{l}1 \cdot 31 \\
0 \cdot 72\end{array}$ & $\begin{array}{l}1 \cdot 45 \\
0 \cdot 67\end{array}$ & $\begin{array}{l}1 \cdot 40 \\
0 \cdot 69\end{array}$ & $\begin{array}{l}1 \cdot 88 \\
0 \cdot 71\end{array}$ & $\begin{array}{l}1 \cdot 69 \\
0 \cdot 88\end{array}$ & $\begin{array}{l}1 \cdot 58 \\
0 \cdot 78\end{array}$ & $\begin{array}{l}\mathbf{1} \cdot 60 \\
0 \cdot 75\end{array}$ \\
\hline Total ....... & $2 \cdot 04$ & $2 \cdot 01$ & $2 \cdot 03$ & $2 \cdot 03$ & $2 \cdot 12$ & $2 \cdot 09$ & $2 \cdot 59$ & $2 \cdot 57$ & $2 \cdot 36$ & $2 \cdot 35$ \\
\hline $\begin{array}{l}\text { Digestible Fibre ............. } \\
\text { Woody Fibre................. }\end{array}$ & $\begin{array}{l}5 \cdot 37 \\
7 \cdot 02\end{array}$ & $\begin{array}{l}5 \cdot 29 \\
6 \cdot 41\end{array}$ & $\begin{array}{l}5 \cdot 51 \\
6 \cdot 15\end{array}$ & $\begin{array}{l}5 \cdot 39 \\
6 \cdot 53\end{array}$ & $\begin{array}{l}5 \cdot 93 \\
6 \cdot 72\end{array}$ & $\begin{array}{l}6 \cdot 13 \\
6 \cdot 70\end{array}$ & $\begin{array}{l}6 \cdot 56 \\
6 \cdot 48\end{array}$ & $\begin{array}{l}7 \cdot 06 \\
6 \cdot 50\end{array}$ & $\begin{array}{l}6 \cdot 45 \\
6 \cdot 67\end{array}$ & $\begin{array}{l}6 \cdot 42 \\
6 \cdot 61\end{array}$ \\
\hline Total ..... & $12 \cdot 39$ & $11 \cdot 70$ & $11 \cdot 66$ & $11 \cdot 92$ & $12 \cdot 65$ & $12 \cdot 83$ & $13 \cdot 04$ & $13 \cdot 56$ & $13: 12$ & $13 \cdot 03$ \\
\hline $\begin{array}{l}\text { Acetic acid................. } \\
\text { Lactic acid............... }\end{array}$ & $\begin{array}{l}0 \cdot 44 \\
0 \cdot 86\end{array}$ & $\begin{array}{l}0 \cdot 19 \\
1 \cdot 18\end{array}$ & $\begin{array}{l}0 \cdot 62 \\
0 \cdot 85\end{array}$ & $\begin{array}{l}0 \cdot 42 \\
0.96\end{array}$ & $\begin{array}{l}0 \cdot 56 \\
1 \cdot 10\end{array}$ & $\begin{array}{l}0 \cdot 76 \\
0 \cdot 84\end{array}$ & $\begin{array}{l}0 \cdot 63 \\
1 \cdot 11\end{array}$ & $\begin{array}{l}0 \cdot 70 \\
0 \cdot 79\end{array}$ & $\begin{array}{l}0 \cdot 73 \\
0 \cdot 81\end{array}$ & $\begin{array}{l}0 \cdot 68 \\
0 \cdot 93\end{array}$ \\
\hline Total ........... & $1 \cdot 30$ & $1 \cdot 37$ & $1 \cdot 47$ & $1 \cdot 38$ & $1 \cdot 66$ & $1 \cdot 60$ & $1 \cdot 74$ & $1 \cdot 49$ & $1 \cdot 54$ & $1 \cdot 61$ \\
\hline $\begin{array}{c}\text { Soluble Carbohydrates, } \\
\text { Amides }(1), \quad \text { Chloro- } \\
\text { phyll, \&c. .................. }\end{array}$ & $3 \cdot 82$ & $3 \cdot 56$ & $4 \cdot 36$ & $3 \cdot 91$ & $5 \cdot 21$ & $4 \cdot 68$ & $5 \cdot 98$ & $6 \cdot 00$ & $6 \cdot 41$ & $5 \cdot 66$ \\
\hline Total of all...... & $100 \cdot 00$ & $100 \cdot 00$ & $100 \cdot 00$ & $100 \cdot 00$ & $100 \cdot 00$ & $100 \cdot 00$ & $100 \cdot 00$ & $100 \cdot 00$ & $100 \cdot 00$ & $100 \cdot 00$ \\
\hline $\begin{array}{l}\text { Albuminoid Nitrogen...... } \\
\text { (1) Non-albuminoid Nitro- } \\
\text { gen ........................... }\end{array}$ & $\left\{\begin{array}{l}0 \cdot 33 \\
0 \cdot 21\end{array}\right.$ & $\begin{array}{l}0 \cdot 35 \\
0 \cdot 17\end{array}$ & $\begin{array}{l}0 \cdot 35 \\
0 \cdot 20\end{array}$ & $\begin{array}{l}0 \cdot 35 \\
0 \cdot 19\end{array}$ & $\begin{array}{l}0 \cdot 34 \\
0 \cdot 17\end{array}$ & $\begin{array}{l}0 \cdot 37 \\
0 \cdot 22\end{array}$ & $\begin{array}{l}0 \cdot 45 \\
0 \cdot 23\end{array}$ & $\begin{array}{l}0 \cdot 40 \\
0 \cdot 26\end{array}$ & $\begin{array}{l}0 \cdot 44 \\
0 \cdot 28\end{array}$ & $\begin{array}{l}0 \cdot 40 \\
0 \cdot 23\end{array}$ \\
\hline Total ... & $0 \cdot 54$ & 0.52 & 0.55 & 0.54 & 0.51 & 0.59 & 0.68 & $0 \cdot 66$ & 0.72 & 0.63 \\
\hline
\end{tabular}

Summary.

\begin{tabular}{|c|c|c|c|c|c|c|c|c|c|c|c|}
\hline Total & (Voelcker ....... & $21 \cdot 61$ & $20 \cdot 83$ & $21 \cdot 70$ & $21 \cdot 38$ & $23 \cdot 76$ & $23 \cdot 51$ & $26 \cdot 16$ & $26 \cdot 12$ & $26 \cdot 18$ & $25 \cdot 15$ \\
\hline & $\{$ Rothamsted * & $21 \cdot 38$ & $20 \cdot 44$ & $21 \cdot 62$ & $21 \cdot 15$ & $23 \cdot 84$ & $22 \cdot 74$ & $25 \cdot 00$ & $25 \cdot 29$ & $25 \cdot 15$ & $24 \cdot 40$ \\
\hline Matter. & Rothamsted $†$ & $21 \cdot 82$ & $20 \cdot 63$ & $22 \cdot 24$ & $21 \cdot 56$ & $24 \cdot 40$ & $23 \cdot 50$ & $25 \cdot 63$ & $25 \cdot 99$ & $25 \cdot 88$ & $25 \cdot 08$ \\
\hline Total & Voelcker ....... & $2 \cdot 04$ & $2 \cdot 01$ & $2 \cdot 03$ & $2 \cdot 03$ & $2 \cdot 12$ & $2 \cdot 09$ & $2 \cdot 59$ & $2 \cdot 57$ & $2 \cdot 36$ & $2 \cdot 35$ \\
\hline Fresh. & $\int$ Rothamsted ... & $1 \cdot 92$ & $1 \cdot 81$ & $1 \cdot 93$ & $1 \cdot 89$ & $2 \cdot 02$ & $1 \cdot 90$ & $2 \cdot 36$ & $2 \cdot 44$ & $2 \cdot 11$ & $2 \cdot 17$ \\
\hline $\begin{array}{c}\text { Total } \\
\text { Nitrogen }\end{array}$ & $\left\{\begin{array}{l}\text { Voelcker ....... } \\
\text { Rothamsted }\end{array}\right.$ & $0 \cdot 54$ & 0.52 & $\begin{array}{l}0.55 \\
0.57\end{array}$ & $0 \cdot 54$ & 0.51 & $0 \cdot 59$ & 0.68 & $0 \cdot 66$ & $0 \cdot 72$ & $0 \cdot 63$ \\
\hline in Fresh. & Rothamsted ... & 0.56 & 0.53 & 0.57 & $0 \cdot 55$ & $0 \cdot 54$ & 0.54 & $0 \cdot 65$ & 0.67 & 0.69 & 0.62 \\
\hline
\end{tabular}


Analyses of the Silage from Silo No. 1; First and Second Crop Red Cloter.

\author{
Complete Analyses by Dr. J. A. Voelceker; \\ Partial Analyses made at Rothamsted.
}

Table VI.-Per Cent. in Dry Matter. Detailed Analyses of each Layer.

\begin{tabular}{|c|c|c|c|c|c|c|c|c|c|c|}
\hline & \multirow{2}{*}{\multicolumn{4}{|c|}{$\begin{array}{l}\text { 2nd Crop Red Clover. } \\
\text { Depth of Silage } 4 \text { feet. }\end{array}$}} & \multicolumn{6}{|c|}{ ] st Crop Red Clover. } \\
\hline & & & & & \multicolumn{2}{|c|}{$\begin{array}{l}\text { Ist depth, } \\
4 \text { feet } 2 \text { incnes. }\end{array}$} & \multicolumn{2}{|c|}{$\begin{array}{l}\text { 2nd depth, } \\
4 \text { feet. }\end{array}$} & \multirow{2}{*}{\begin{tabular}{|c|} 
3rd \\
depth, \\
5 feet. \\
2 Sample 1 \\
taken \\
Mar. 12, \\
I 885.
\end{tabular}} & \multirow{2}{*}{ Mean. } \\
\hline & $\begin{array}{c}\text { Sample } 1 \\
\text { taken } \\
\text { Dec. 13, } \\
\text { 1884. }\end{array}$ & $\begin{array}{c}\text { Sample } 2 \\
\text { taken } \\
\text { Dec. } 18 \\
1884\end{array}$ & $\begin{array}{c}\text { Sample } 3 \\
\text { taken } \\
\text { Dec. } 30 \\
1884\end{array}$ & Mean. & $\begin{array}{c}\text { Sample } 1 \\
\text { taken } \\
\text { Jan. 17, } \\
1885 .\end{array}$ & $\begin{array}{c}\text { Sample 2 } \\
\text { taken } \\
\text { Jan. 23, } \\
1885 .\end{array}$ & $\begin{array}{c}\text { Sample } 1 \\
\text { taken } \\
\text { Feb. 6, } \\
1885 .\end{array}$ & $\begin{array}{c}\text { Sample 2 } \\
\text { taken } \\
\text { Feb. 17, } \\
1885 .\end{array}$ & & \\
\hline $\begin{array}{l}\text { Soluble Albuminoids ...... } \\
\text { Insoluble Albuminoids ... }\end{array}$ & $\begin{array}{c}\text { P. cent. } \\
0.56 \\
8.97\end{array}$ & $\begin{array}{c}\text { P. cent. } \\
2 \cdot 11 \\
8 \cdot 40\end{array}$ & $\begin{array}{c}\text { P. cent. } \\
2 \cdot 26 \\
7 \cdot 79\end{array}$ & $\begin{array}{c}\text { P. cent. } \\
1 \cdot 64 \\
8 \cdot 39\end{array}$ & $\begin{array}{c}\text { P. cent. } \\
1 \cdot 30 \\
7 \cdot 62\end{array}$ & $\begin{array}{c}\text { P. cent. } \\
2 \cdot 13 \\
7 \cdot 70\end{array}$ & $\begin{array}{c}\text { P. cent. } \\
3 \cdot 36 \\
7 \cdot 38\end{array}$ & \begin{tabular}{|c} 
P. cent. \\
$2 \cdot 87$ \\
$6 \cdot 70$
\end{tabular} & $\mid \begin{array}{c}\text { P. cent. } \\
2 \cdot 14 \\
8 \cdot 37\end{array}$ & $\begin{array}{l}\text { P. cent. } \\
2 \cdot 36 \\
7 \cdot 56\end{array}$ \\
\hline Total .................... & $9 \cdot 53$ & $10 \cdot 51$ & $10 \cdot 05$ & $10 \cdot 03$ & $8 \cdot 92$ & $9 \cdot 83$ & $10 \cdot 74$ & $9 \cdot 57$ & $10 \cdot 51$ & $9 \cdot 9 \cdot 2$ \\
\hline 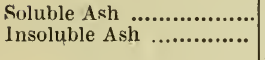 & $\begin{array}{l}5 \cdot 92 \\
3 \cdot 52\end{array}$ & $\begin{array}{l}6 \cdot 58 \\
3 \cdot 07 \\
\end{array}$ & $\begin{array}{l}5 \cdot 90 \\
3 \cdot 46 \\
\end{array}$ & $\begin{array}{l}6 \cdot 13 \\
3 \cdot 35 \\
\end{array}$ & $\begin{array}{l}6 \cdot 10 \\
2 \cdot 82\end{array}$ & $\begin{array}{l}5 \cdot 96 \\
2 \cdot 93 \\
\end{array}$ & $\begin{array}{l}7 \cdot 19 \\
2: 71 \\
\end{array}$ & $\begin{array}{l}6 \cdot 47 \\
3 \cdot 37 \\
\end{array}$ & $\begin{array}{l}6 \cdot 03 \\
2 \cdot 98 \\
\end{array}$ & $\begin{array}{l}6 \cdot 35 \\
2 \cdot 96 \\
\end{array}$ \\
\hline Total .................... & $9 \cdot 44$ & $9 \cdot 65$ & $9 \cdot 36$ & $9 \cdot 48$ & $8 \cdot 92$ & $8 \cdot 89$ & $9 \cdot 90$ & $9 \cdot 84$ & $9 \cdot 01$ & $9 \cdot 31$ \\
\hline $\begin{array}{l}\text { Digestible Fibre } \\
\text { Woody Fibre }\end{array}$ & $\begin{array}{l}24 \cdot 85 \\
32 \cdot 48\end{array}$ & $\begin{array}{l}25: 40 \\
30 \cdot 77\end{array}$ & $\begin{array}{l}25 \cdot 39 \\
28 \cdot 34\end{array}$ & $\begin{array}{l}25 \cdot 21 \\
30 \cdot 53\end{array}$ & $\begin{array}{l}24 \cdot 96 \\
28 \cdot 28\end{array}$ & $\begin{array}{l}26 \cdot 07 \\
28: 50\end{array}$ & $\begin{array}{l}25 \cdot 08 \\
24 \cdot 77\end{array}$ & $\begin{array}{l}27 \cdot 03 \\
24 \cdot 89\end{array}$ & $\begin{array}{l}24 \cdot 64 \\
25 \cdot 48\end{array}$ & $\begin{array}{l}25 \cdot 56 \\
26 \cdot 38\end{array}$ \\
\hline Total …............... & $57 \cdot 33$ & $56 \cdot 17$ & $53 \cdot 73$ & $55 \cdot 74$ & $\overline{53} \cdot \overline{24}$ & $54 \cdot 57$ & $49 \cdot 85$ & อิ1 92 & $50 \cdot 12$ & $51 \cdot 94$ \\
\hline $\begin{array}{l}\text { Acetic Acid } \\
\text { Lactic Acid }\end{array}$ & $\begin{array}{l}2 \cdot 04 \\
3 \cdot 98 \\
\end{array}$ & $\begin{array}{l}0 \cdot 91 \\
5 \cdot 67\end{array}$ & $\begin{array}{l}2: 86 \\
3 \cdot 91\end{array}$ & $\begin{array}{l}1 \cdot 94 \\
4 \cdot 52\end{array}$ & $\begin{array}{l}2 \cdot 36 \\
4 \cdot 63\end{array}$ & $\begin{array}{l}3 \cdot 23 \\
3 \cdot 57\end{array}$ & $\begin{array}{l}2 \cdot 41 \\
4 \cdot 24 \\
\end{array}$ & $\begin{array}{l}2 \cdot 68 \\
3 \cdot 02 \\
\end{array}$ & $\begin{array}{l}2 \cdot 79 \\
3 \cdot 09 \\
\end{array}$ & $\begin{array}{l}2 \cdot 69 \\
3 \cdot 71 \\
\end{array}$ \\
\hline Total $\ldots \ldots \ldots \ldots$ & $6 \cdot 02$ & $6 \cdot 58$ & $6 \cdot 77$ & $6 \cdot 46$ & $6 \cdot 99$ & $6: 80$ & $6 \cdot 65$ & $5 \cdot 70$ & $5 \cdot 88$ & $6 \cdot 40$ \\
\hline $\begin{array}{l}\text { Soluble Carbohydirates, } \\
\text { Amides (1), Chloro- } \\
\text { phyll, \&c. ........................ }\end{array}$ & \} $17 \cdot 68$ & $17 \cdot 09$ & $20 \cdot 09$ & $18 \cdot 29$ & $21 \cdot 93$ & $19 \cdot 91$ & $22 \cdot 86$ & $22 \cdot 97$ & $24 \cdot 48$ & $22 \cdot 43$ \\
\hline Total of all $\quad . . . .$. & $10 \cdot \cdot 00$ & $100 \cdot 00$ & $100 \cdot 00$ & $100 \cdot 00$ & $100 \cdot 10$ & $100 \cdot 00$ & $100 \cdot 00$ & $100 \cdot 00$ & $100 \cdot 00$ & $100 \cdot 00$ \\
\hline $\begin{array}{l}\text { Albuminoid Nitrogen } \\
\text { (1) Non-albuminoid Nitro- } \\
\text { gen ........................................ }\end{array}$ & $\begin{array}{l}1 \cdot 53 \\
0 \cdot 97\end{array}$ & $\begin{array}{l}1 \cdot 68 \\
0 \cdot 82 \\
\end{array}$ & $\begin{array}{l}1 \cdot 61 \\
0.92 \\
\end{array}$ & $\begin{array}{r}1 \cdot 61 \\
0 \cdot 90 \\
\end{array}$ & $\begin{array}{l}1 \cdot 43 \\
0 \cdot 72 \\
\end{array}$ & $\begin{array}{l}1.57 \\
0.94 \\
\end{array}$ & $\begin{array}{l}1 \cdot 72 \\
0 \cdot 88 \\
\end{array}$ & $\begin{array}{l}1 \cdot 53 \\
1 \cdot 00 \\
\end{array}$ & $\begin{array}{l}1 \cdot 68 \\
1 \cdot 07 \\
\end{array}$ & $\begin{array}{l}1 \cdot 59 \\
0 \cdot 92 \\
\end{array}$ \\
\hline Total .................... & $2 \cdot 50$ & $2 \cdot 50$ & $2 \cdot 53$ & $2 \cdot 51$ & $2 \cdot 15$ & $2 \cdot 51$ & $2 \cdot 60$ & $2 \cdot 53$ & $2 \cdot 75$ & $2 \cdot 51$ \\
\hline
\end{tabular}

\title{
Șummary.
}

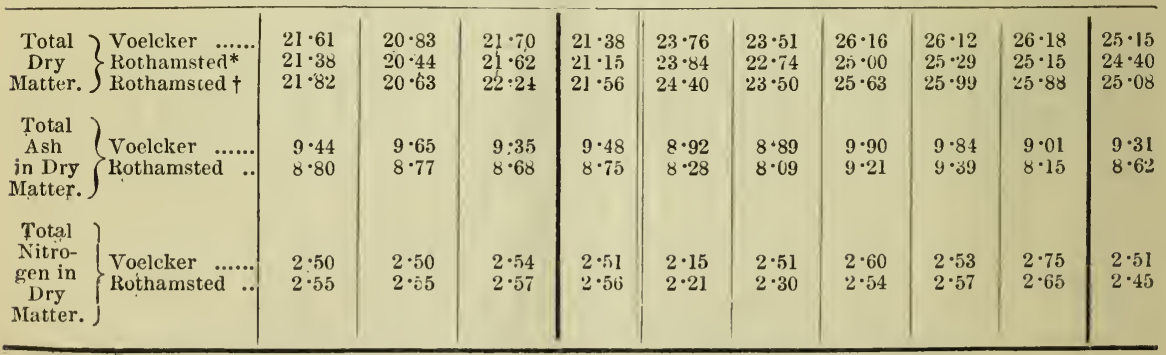


The percentage of "woody fibre" is considerably higher in the dry substance of the silage than it was found to be in that of the herbage put in; and, so far as the results enable us to calculate, there was na reduction in the total amount of woody fibre put into the silo. The differences in the percentages of woody fibre in the different samples of silage which the analyses show, might, at first sight, lead to the conclusion that there has been a reduction in its percentage, and in its amount, in the lower layers; and the results might further be supposed to indicate a somewhat corresponding increase in the soluble extractive matters (soluble carbohydrates, \&c.). Bat a careful consideration of the differences in the condition of maturation, and in the composition accordingly, of the herbage contributing to the several layers of silage, shows that the differences in the composition of the latter in these respects, are obviously connected with differences in the character of the herbage put in.

As to the relative proportions of solubie and insoluble albuminoids in the silage, it is obvious that they, too, are largely dependent on the conditions of succulence, or of ripeness, of the herbage put in; though some of the results seem to favour the view that a portion of the insoluble albuminoids has become soluble. According to the results given in Table II ( $p, 12)$, there was a loss of about 8 per cent. of the total nitrogen of the herbage put into the silo; and the analytical results now given show that, of the total nitrogen in the silage from the first crop clover, there was an average of 36.8 per cent. in a non= albuminoid condition; whilst initiative results show that, in the herbage put in, less than 20 per cent. of the total nitrogen was nonalbuminoid. Again, of the total nitrogen of the second-crop cloversilage, there was an average of 36 per cent. non-albuminoid; whilst in the very ripe herbage put in, only about 10 per cent. of the total nitrogen was non-albuminoid. These results are quite in accordance with those obtained by Professor Kinch, Mr. Clifford Richardson, the late Dr. Voelcker, Mr. W. H. Jordan, and others.

Thus, not only is there a loss of nitrogenous food-material, but a very considerable proportion of the nitrogenous substance which remains is degraded into compounds, some of which are of no value as food (ammonia for example), whilst others, forming a much larger proportion, are, to say the least, of reduced food-value. Further, besides the loss, and the degradation, of nitrogenous substance, it has been shown that there was also more or less loss of non-nitrogenous matter; whilst there is no evidence that woody fibre of a certain degree of induration has been rendered more soluble.

It remains to see what are the results of the experiments on the fecding of animals with the silage. 


\section{5.-Experiments with Fatrening Oxen.}

In the beginning of December, 1884, 10 oxen were selected from a herd of 40 Irish shorthorns, of good quality, which cost about $16 l$. a head delivered at Rothamsted a short time previously. On December 19th, they were weighed, and divided into two lots of five each ; care being taken that the two lots should correspond as far as possible, both as to the character of the animals, and in weight. The difference in the average weight per head of the two lots, was, at the commencement of the experiment, only $12 \mathrm{lbs}$. For the purpose of the experiment they were placed in ten boxes under the same roof; one lot of five facing the other lot of five.

The experiment was arranged to compare the feeding value of redclover-silage with that of an ordinary winter food for fattening stock-namely, a mixture of clover-hay-chaff and swedes. Besides these foods, which were to be tried one against the other, each animal received the same description and amount of purchased or saleable food; namely, $6 \mathrm{lbs}$. of cake, and $4 \frac{1}{2} \mathrm{lbs}$. of barley-meal, per head per day. Of the experimental foods, one lot received an average of rather more than $65 \mathrm{lbs}$. of clover-silage per head per day; and the other lot $12 \mathrm{lbs}$. of clover-hay-chaff, and an average of about $50 \mathrm{lbs}$. of swedes, per head per day. As far as we could calculate beforehand, the quantity of dry substance in the silage given to the one lot, would be nearly the same as that in the clover-hay and swedes given to the other lot.

Table VII (p. 25) shows the exact amounts of the various foods consumed per head per day by each lot. In the particulars of the foods weighed off it will be noticed that some cake was included. This consisted of the harder pieces of decorticated cotton-cake, which has been unusually hard of late. It would have been better to have picked this out, and weighed it separately. It will be seen, however, that the oxen on silage had more than $75 \mathrm{lbs}$. of the mixed foods per head per day, of which, on the average, only about $1 \frac{1}{3} \mathrm{lb}$. was weighed off. Reckoning one-fourth of this to have been cake and three-fourths silage, and that of the food weighed off from Lot 2, one-third was cake, one-third chaff, and one-third swedes, calculation shows that the silage oxen consumed about $\frac{1}{2} \mathrm{lb}$. more dry substance of food per head per day than the others; but this larger amount of dry substance contained a somewhat larger proportion of woody fibre. The total amount of dry substance consumed was, in both cases, on the average, between 24 and $25 \mathrm{lbs}$. per head per day; and the quantity of nitrogen consumed was practically identical in the two cases. 
EXPERIMENTS ON THE FEEDING OF OXEN.

Table VII.-Food Consumed per Head per Day.

Lot 1.-5 Oxen; Experimental Food-Clover Silage.

Food given per Head per Day.

Periods.

December 19-December $31=13$ days.

January 1-February $10=41$

February 11-March $16=34$.

March 17-April $11=26 \quad$, .

,. 70

, 65

Total...........114 days.

\begin{tabular}{|c|c|c}
$\begin{array}{c}\text { Clover- } \\
\text { silage. }\end{array}$ & Cake.* $^{\text {Carley }}$ & $\begin{array}{c}\text { Barl. } \\
\text { mcal. }\end{array}$ \\
\hline lbs. & lbs. & lbs. \\
65 & 6 & $4 \frac{1}{2}$ \\
70 & 6 & $4 \frac{1}{2}$ \\
65 & 6 & $4 \frac{1}{2}$ \\
65 & 5 & $4 \frac{1}{2}$ \\
\hline- & - & -
\end{tabular}

\begin{tabular}{|c|c|c|c|c|}
\hline \multicolumn{5}{|c|}{ Food Weighed off. } \\
\hline January & $7 \ldots \ldots \ldots \ldots$ & $20 \mathrm{lbs}$. & .. & Chiefly silage. \\
\hline January & $26 \ldots \ldots \ldots \ldots \ldots$ & 90 & $\ldots \ldots \ldots \ldots$ & Chiefly silage. \\
\hline February & $10 \ldots \ldots \ldots \ldots$ & 168 & $\ldots \ldots \ldots \ldots$ & Silage and cake. \\
\hline February & $20 \ldots \ldots \ldots \ldots$ & 92 & .. . & Silage and cake. \\
\hline February & $28 \ldots \ldots \ldots \ldots$ & 124, & $\ldots \ldots \ldots \ldots$ & Silage and cake. \\
\hline March & $9 \ldots \ldots \ldots \ldots \ldots$ & 38 & $\ldots \ldots \ldots \ldots$ & Chiefly silage. \\
\hline March & $16 \ldots \ldots \ldots \ldots$ & 116 & ........... & Silage and cake. \\
\hline April & $9 \ldots \ldots \ldots \ldots$ & 78 & $\ldots \ldots \ldots \ldots$ & Chiefly silage. \\
\hline April & $11 \ldots \ldots \ldots \ldots$ & 57, & $\ldots \ldots \ldots \ldots$ & Silage and a little cake. \\
\hline & & 783 lbs. & Per he & d per day $1 \cdot 36 \mathrm{lb}$. \\
\hline
\end{tabular}

Lot 2.-5 Oxen; Experimental Food-Clover-chaff and Swedes.

Food given per Head per Day.

Periods.

\begin{tabular}{|c|c|c|c}
$\begin{array}{c}\text { Clover- } \\
\text { chaff. }\end{array}$ & Swedes. & Cake* & $\begin{array}{c}\text { Barley } \\
\text { meal. }\end{array}$ \\
\hline lbs. & lbs. & lbs. & lbs. \\
12 & 40 & 6 & $4 \frac{1}{2}$ \\
12 & 60 & 6 & $4 \frac{1}{2}$ \\
12 & 50 & 6 & $4 \frac{1}{2}$ \\
12 & 50 & 5 & $4 \frac{1}{2}$ \\
\hline- & - & - & -
\end{tabular}

December 19-December $31=13$ days January 1-January $7=7$, January 8-March $16=68$, , . March 17-April $11=26$ ",

Total ......... 114 days.

\section{Food Weighed off.}

\begin{tabular}{|c|c|c|c|c|}
\hline January & 7 & $35 \mathrm{lbs}$. & & Chaff and swedes. \\
\hline March & 16 & & & Chaff, swedes, and cake. \\
\hline March & $23 \ldots$ & 46 & .. & Chaff and swedes. \\
\hline April & $11 \ldots \ldots \ldots \ldots$ & 34, & $\ldots \ldots \ldots \ldots$ & Chaff, swedes, and cake. \\
\hline
\end{tabular}

Total .......... 200 lbs.

Per head per day .... $0.35 \mathrm{lb}$.

* December 19 to February 4 (48 days) an equal mixture of linseed and decorticated cotton-cake; February 5 to April 11 (66 days) decorticated cotton-cake only. 
The following Table (VIII) shows the weight of each animal at the commencement, at two intermediate periods, and at the conclusion of the experiment; also the gain in weight within each period, and over the total period of 16 weeks and 2 days. It further shows, for each lot, and for each period, the average increase per head per week, and the average increase per $1000 \mathrm{lbs}$. live-weight per week.

Taking the results for the whole period, whether we compare the total increase, the average increase per head, the ivcrease per head per week, or per $1000 \mathrm{lbs}$. live-weight per week, there is a very close agreement between the two lots, the one receiving clover-silage, and the other very nearly the same amount of dry substance in clover-hay-chaff and swedes. The silage has slightly the advantage; but the difference is not more than might be expected in two lots of oxen fed on precisely the same food. Both lots did remarkably well ; the silage oxen giving an average increase of rather more, and the others of rather less, than $1 \frac{1}{2}$ per cent. of their live-weight per week. There can be

Experiments on the Feeding of Oxen.

TABLE VIII.-Actual Weights, and Increase in Weight of the Oxen.

\begin{tabular}{|c|c|c|c|c|c|c|c|c|}
\hline \multirow[b]{2}{*}{ Oxen. } & \multicolumn{4}{|c|}{ Actual weights. } & \multicolumn{4}{|c|}{ Increase in weight. } \\
\hline & $\begin{array}{c}\text { Dec. } 19, \\
1884 .\end{array}$ & $\begin{array}{c}\text { Jan. } 30, \\
1885 .\end{array}$ & $\begin{array}{c}\text { Feb. } 28 \\
1885 .\end{array}$ & $\begin{array}{l}\text { April 11, } \\
1885 .\end{array}$ & $\begin{array}{l}\text { Dec. } 19 \\
\text { to Jan. } 30 \text {, } \\
43 \text { days. }\end{array}$ & $\begin{array}{c}\text { Jan. } 30 \\
\text { to Feb. } 28, \\
29 \text { days. }\end{array}$ & $\begin{array}{l}\text { Feb. } 28 \\
\text { to April } 11 \\
12 \text { days. }\end{array}$ & $\begin{array}{c}\text { Total } \\
\text { Dec. } 19 \\
\text { to April 11, } \\
114 \text { days. }\end{array}$ \\
\hline
\end{tabular}

Lot 1.-5 Oxen; Experimental Food-Clover-silage.

\begin{tabular}{|c|c|c|c|c|c|c|c|c|}
\hline 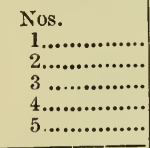 & $\begin{array}{l}\text { lbs. } \\
1055 \\
1132 \\
1086 \\
1048 \\
1020\end{array}$ & $\begin{array}{l}\text { lbs. } \\
1145 \\
1330 \\
1224 \\
1213 \\
1171\end{array}$ & $\begin{array}{l}\text { lbs. } \\
1183 \\
1421 \\
1263 \\
1260 \\
1253\end{array}$ & $\begin{array}{l}\text { lbs. } \\
1281 \\
1547 \\
1344 \\
1365 \\
1351\end{array}$ & $\begin{array}{r}\text { lbs. } \\
90 \\
198 \\
138 \\
165 \\
151\end{array}$ & $\begin{array}{l}\text { lbs. } \\
38 \\
91 \\
39 \\
47 \\
82\end{array}$ & $\begin{array}{r}\text { lbs. } \\
98 \\
1 \geq 6 \\
81 \\
105 \\
98\end{array}$ & $\begin{array}{l}\text { lbs. } \\
226 \\
415 \\
258 \\
317 \\
331\end{array}$ \\
\hline $\begin{array}{l}\text { 'Total............ } \\
\text { A verage ..... }\end{array}$ & $\begin{array}{l}5341 \\
1068\end{array}$ & $\begin{array}{l}6083 \\
1217\end{array}$ & $\begin{array}{l}6380 \\
12,6\end{array}$ & $\begin{array}{l}6888 \\
1378\end{array}$ & $\begin{array}{l}742 \\
149\end{array}$ & $\begin{array}{r}297 \\
59\end{array}$ & $\begin{array}{r}508 \\
-\quad 102\end{array}$ & $\begin{array}{r}1547 \\
310\end{array}$ \\
\hline \multicolumn{5}{|c|}{ 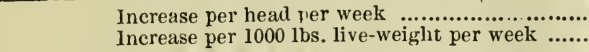 } & $\begin{array}{l}24 \cdot 3 \\
21 \cdot 2\end{array}$ & $\begin{array}{l}14 \cdot 2 \\
11 \cdot 4\end{array}$ & $\begin{array}{l}17: 0 \\
12 \cdot 8\end{array}$ & $\begin{array}{l}19 \cdot 0 \\
15 \cdot 6\end{array}$ \\
\hline
\end{tabular}

Lot 2.-Oxen; Experimental Food-Clover-chaff and Swedes.

\begin{tabular}{|c|c|c|c|c|c|c|c|c|}
\hline $\begin{array}{l}1 \ldots \ldots \ldots \ldots \ldots \\
2 \ldots \ldots \ldots \ldots \ldots \\
3 \ldots \ldots \ldots \ldots \ldots \\
4 \ldots \ldots \ldots \ldots \\
5 \ldots \ldots \ldots \ldots\end{array}$ & $\begin{array}{l}1055 \\
1068 \\
1020 \\
11 \cdot 25 \\
1132\end{array}$ & $\begin{array}{l}1231 \\
1229 \\
1166 \\
1257 \\
1334\end{array}$ & $\begin{array}{l}1265 \\
1260 \\
1186 \\
1270 \\
1390\end{array}$ & $\begin{array}{l}1347 \\
1327 \\
1288 \\
1393 \\
1519\end{array}$ & $\begin{array}{l}176 \\
161 \\
146 \\
132 \\
202\end{array}$ & $\begin{array}{l}34 \\
31 \\
20 \\
13 \\
56\end{array}$ & $\begin{array}{r}82 \\
67 \\
102 \\
123 \\
-129\end{array}$ & $\begin{array}{l}292 \\
25 y \\
268 \\
268 \\
387\end{array}$ \\
\hline Total ............ & $\begin{array}{l}5400 \\
1080\end{array}$ & $\begin{array}{l}6217 \\
1: 43\end{array}$ & $\begin{array}{l}6371 \\
1274\end{array}$ & $\begin{array}{l}6874 \\
1375\end{array}$ & $\begin{array}{l}817 \\
163\end{array}$ & $\begin{array}{r}154 \\
31\end{array}$ & $\begin{array}{l}503 \\
101\end{array}$ & $\begin{array}{r}1474 \\
295\end{array}$ \\
\hline \multicolumn{5}{|c|}{$\begin{array}{l}\text { Increase per head per week............................ } \\
\text { Increase per } 1000 \text { lbs. live-weight per week .... }\end{array}$} & $\begin{array}{l}26 \cdot 5 \\
22 \cdot 8\end{array}$ & $\begin{array}{l}7 \cdot 5 \\
5 \cdot 9\end{array}$ & $\begin{array}{l}16 \cdot 8 \\
12 \cdot 7\end{array}$ & $\begin{array}{l}38 \cdot 1 \\
14 \cdot 8\end{array}$ \\
\hline
\end{tabular}


no doubt, therefore, that well made red-clover-silage is a very good food for fattening oxen.

About 25 years ago, from the results then at command, we concluded that fattening oxen, liberally fed on good food, composed of a moderate proportion of cake or corn, some hay or straw-chaff, and roots, would, on the average, consume 12 to $13 \mathrm{lbs}$. of the dry substance of such mixed food per 100 lbs. live-weight per week, and should give $1 \mathrm{lb}$. of increase in live-weight for 12 or $13 \mathrm{lbs}$. dry substance of food so consumed; that is 1 per cent. increase in live-weight per week. In these new experiments the oxen receiving silage consumed rather over, and those receiving clover-chaff and swedes rather under, 14 lbs. of dry substance of food per 100 lbs. live-weight per week; and the former gave $1 \mathrm{lb}$. increase for a little over $9 \mathrm{lbs}$., and the latter for about $9 \frac{1}{3} \mathrm{lbs}$. dry substance of food consumed. In other words, both lots consumed rather more dry substance of food per. 100 lbs. live-weight per week than according to our former estimates; but they gave considerably more increase, both upon a given liveweight within a given time (about $1 \frac{1}{2}$ instead of 1 per cent. per week), and for a given amount of dry substance of food consumed.

It will be seen that the amount of cake and meal given was rather large, together amounting to $10 \frac{1}{2} \mathrm{lbs}$. per head per day. It was, however, thought desirable that the fattening should be completed, or nearly completed, when the experiment closed. It is a question how far the better result than formerly is due to the large proportion of cake and meal; how far to improvement in the fattening qualities of stock since that time; and how far to the fact that, with earlier maturity, the increase in live-weight represents a considerable proportion of growth as well as fattening increase. It may be added that four of the oxen were sold by auction at Watford, and fetched 25l. $6 s$. $3 d$. per head; whilst the others were sold at intervals during seven weeks, and averaged $24 l .12 s .6 d$. per head.

So far then as the results of a single experiment can be relied upon, it would seem that, as food for fattening oxen, a given amount of dry substance in red-clover-silage is quite equal to the same amount of dry substance in a mixture of clover-hay-chaff and swedes, given in the proportion of 12 parts chaff to 50 parts swedes.

It will be of interest to consider-what would be the difference in the cropping of the farm, to produce clover-silage on the one hand, or clover-hay-chaff and swedes, on the other, in the proportions used in these experiments with oxen. Supposing that, to give a herd of oxen $65 \mathrm{lbs}$. of clover-silage per head per day, we had to produce 65 tons of the silage; and for the $12 \mathrm{lbs}$. of clover-hay and $50 \mathrm{lbs}$. of swedes, per head per day, we had to produce 12 tons of clover-hay, and 50 tons of swedes-how much land would be 
required in the two cases? A fairly good crop of red clover, cut twice, wonld weigh about 10 tons per acre in the green or fresh state; and according to the results with No. 1 Silo, this would yield only about $7 \frac{1}{2}$ tons of clover-silage, so that it would require $8 \frac{3}{4}$ acres to produce the 65 tons of silage. The 10 tons of first and second crop green clover would make about $2 \frac{1}{2}$ tons of clover-hay; so that it would require about $4 \frac{3}{4}$ acres to produce the 12 tons of clover-hay. There would thus remain about 4 acres at disposal for the production of the 50 tons of swedes.

6.-Food Required for mere Sustenance, for the Production or Milk, and for the Production of Fattening Increase.

Before referring to the plan and the results of the experiments with cows, it may be well, with a view to the better understanding of the subject, to make some remarks on food generally, and especially to call attention to the distinction between the amount of food required for the mere sustenance of the animal, and the amount required for the production of the milk.

In the various accounts which have been published of experiments on silage, nothing is more striking than the extraordinary results which are stated to have been obtained by its use. In several cases, the use of an amount of the material which, according to calculation, would not contain more dry substance of food than would be sufficient to support the life of the cow, has, it has been stated, been followed by a remarkable increase in the production of milk and butter. The authors of these statements have, probably, no doubt of their accuracy; but they depend upon others for the record of the facts; and those employed usually try to make these come out so as to meet the views of their masters, if they take an interest in the new food.

The ordinary dry foods of the farm-hay, straw, and corn-contain about one-sixth of their weight of water, and five-sixths of real dry substance. Whenever the foods given to cows have been carefully weighed, and the dry matter determined, it has been found that a cow of ordinary size, and in ordinary milking condition, will consume not less than 25 lbs. of "dry substance" of food daily.

For example, 40 years ago, Drs. Thomas and Robert Dundas Thomson carried out some feeding experiments at Glasgow, with cows of the Ayrshire breed, weighing about $1000 \mathrm{lbs}$. each. They used grass alone, or hay, with various dry foods. The cows were yielding about 2 gallons (about $20 \frac{2}{3}$ lbs.) of milk per head per day, and the dry substance of food varied from $25 \mathrm{lbs}$. to $30 \mathrm{lbs}$. per head per day. The higher amount, which was that consumed when an additional 
quantity of corn or linseed was given, yielded only a slight increase in the milk.

About 25 years ago we conducted experiments with cows and oxen, at Rugby, for the Royal Sewage Commission, trying unsewaged against sewaged grass, and the same with oilcake in addition. The various experiments were made in 1861, 1862, and 1863. We will confine attention here to the experiments with cows. The average weight of the animals was between 1000 and $1100 \mathrm{lbs}$. The average of five experiments with grass alone-some unsewaged and some sewaged-showed that $28.7 \mathrm{lbs}$. of dry substance of food were consumed per head per day, with an average yield of $26 \frac{1}{2} \mathrm{lbs}$. of milk per head per day. And the average of five experiments with grass and oilcake showed a consumption of $28.4 \mathrm{lbs}$. of dry substance of food per head per day, with a yield of $25 \frac{1}{2} \mathrm{lbs}$. of milk per head per day.

Again, in the course of experiments which we conducted for the Board of Trade on the relative values of unmalted and malted barley, as food for stock, cows, oxen, sheep, and pigs were experimented upon; and in the case of the 20 cows, of which the average weight was $1140 \mathrm{lbs}$., and the average yield of milk about $23 \mathrm{lbs}$. per head per day, the average consumption, over a period of 10 weeks, during the winter of 1863-4, amounted to about $29 \frac{1}{2}$ lbs. dry substance of food per head per day.

In 1884, we assisted $\mathrm{Mr}$. Edwards, who has a large dairy of highly-bred shorthorns at St. Albans, in carrying out some experiments upon ensilage; and it was found, on calculation, that, in the three experiments, the food supplied $28 \frac{1}{2} \mathrm{lbs}$., $27 \mathrm{lbs}$., and $27 \mathrm{lbs}$., per head per day, of real dry substance; whilst the three lots were yielding, respectively, an average of $19 \frac{3}{4} \mathrm{lbs}$., $17 \mathrm{lbs}$., and scarcely $17 \mathrm{lbs}$. of milk, per head per day. It may be mentioned that these were unusually heavy cows, one indeed weighed over $1700 \mathrm{lbs}$, and the 26 cows gave an average of $1413 \mathrm{lbs}$.

Again, in the spring of 1884, the dry food consumed by the Rothamsted cows, when yielding $30 \mathrm{lbs}$. of milk per head per day, was about $26 \mathrm{lbs}$.

It is usually said that it requires about three acres of grass to support. a cow for a year. If we estimate an acre of ordinary meadow land, when fed or mown, to yield a produce equal to $1 \frac{1}{2}$ tons of hay per acre, three acres of such produce would furnish a cow with an average $23 \mathrm{lbs}$. of dry substance of food per day during the year; if the produce were equal to $1 \frac{3}{4}$ tons of hay per acre, 3 acres would supply an average of $26.8 \mathrm{lbs}$. of dry substance per day for a year'; or if the yield were equal to 2 tons of hay per acre, it would supply an average of $30.7 \mathrm{lbs}$. of dry substance of food per day, the year round. The land would of course yield much more than its average quantity 
during the summer, and much less during the winter; whilst a cow would consume more than its average amount when yielding milk, and less when dry.

It will be seen that there is a fairly general agreement between the figures brought out in the foregoing cases; certainly quite sufficient, not only to raise doubts as to the accuracy of any results which differ materially from them, but also sufficient to provide practical farmers with some basis upon which to calculate the requirements of their stock during the six winter months.

So far, we have only treated of the amount of dry substance of food consumed by a cow that is yielding milk. It is evident, however, that the different foods must vary considerably in their composition, and consequently in their feeding qualities, as also they vary in their cost; and as; in all dairies, the yield of milk varies considerably, not only according to the milk-yielding capacity of the individual cows, but also owing to the necessary fluctuations in the yield from the time of calving to dryness, an accurate knowledge of the feeding qualities of different descriptions of food ought to lead to economy in their use.

For many years past, important investigations have been carried on in Germany, especially at Weende, by Henneberg and others, relating to the digestibility of the various constituents contained in different foods, and also as to the amounts of the digestible substances which are required to support life:

What is called the "sustenance food" of an animal, is the amount which will supply the waste of the body in a state of rest, without either gain or loss of weight. For example, it was found that a ration of $19 \frac{1}{2} \mathrm{lbs}$ : of clover hay supplied to an ox weighing $1000 \mathrm{lbs}$, was sufficient to keep up this weight, without adding to it, the animal doing no work, and the temperature of the stall being kept at about $51^{\circ}$ Fahrenheit. Of this $19 \frac{1}{2} \mathrm{lbs}$. of hay, $\frac{5}{6} \mathrm{lb}$. of nitrogenous, and nearly $7 \frac{3}{4} \mathrm{lbs}$. of non-nitrogenous substances, were digested. Other rations were also experimented upon-such as clover hay, straw, and rape cake, in different proportions, and clover hay, mangels, straw, and rape cake. The mean of five experiments, including that with the clover hay alone, showed $0.57 \mathrm{lb}$. of digestible nitrogenous, and $7 \cdot 4 \mathrm{lbs}$. of digestible non-nitrogenous substances, to be required for the support of the animal without gaining or losing weight; but in two of the cases the temperature of the stall was about $62^{\circ} \mathrm{F}$., and in the other two it was about $69^{\circ}$ F. From results of this kind, both Professor Julius Kühn and Professor Emil v. Wolff have constructed tables which give the amounts of digestible substances that may be expected to be present in a great variety of foods. 
Owing to the great difference in the feeding qualities of the same description of food-whether it be roots, hay, corn, or purchased foodit is evident that these tables require to be used with caution; still, when so used, they are of considerable value. We now propose, therefore, to apply them to the results obtained at Rothamsted in the spring of 1884, from 30 cows, each of which consumed daily 4 lbs. decorticated cotton-cake, $3 \frac{1}{2} \mathrm{lbs}$. bran, $3.6 \mathrm{lbs}$. hay chaff, $7 \cdot 2 \mathrm{lbs}$. oatstraw chaff, and $81 \mathrm{lbs}$. mangels, and yielded $30 \mathrm{lbs}$. of milk per head per day.

The following Table (IX) shows that the food supplied an average of about $25 \frac{3}{4} \mathrm{lbs}$. dry substance per head per day. It also gives the quantities of digestible nitrogenous and non-nitrogenous substances in the foods, calculated according to our own estimates of average composition, and to Emil v. Wolff's estimates of the proportion of the several constituents which is digestible. It further shows-the amounts which, according to the German estimates, would be required for the sustenance of one of the cows, the average weight of which was about $1290 \mathrm{lbs}$; the amounts required for the production of $30 \mathrm{lbs}$. of milk; and lastly, the estimated excess in the food:

TABLE IX.-Amount and Distribution of Food; and Food Constituents, per Head per Day.

\begin{tabular}{|c|c|c|c|c|}
\hline & \multirow{2}{*}{$\begin{array}{l}\text { Total dry } \\
\text { substance. }\end{array}$} & \multicolumn{3}{|c|}{ Digestible. } \\
\hline & & $\begin{array}{l}\text { Nitrogenous } \\
\text { substince. }\end{array}$ & $\begin{array}{l}\text { Non-nitro- } \\
\text { gevous } \\
\text { substance.* }\end{array}$ & $\begin{array}{l}\text { Total, } \\
\text { nit. and non- } \\
\text { nit.-sub- } \\
\text { stance. }\end{array}$ \\
\hline $\begin{array}{l}4 \text { lbs. cotton-cake........ } \\
3 \frac{1}{2} \text { lbs. bran ........... } \\
3 \cdot 6 \text { lbs. hay chaff. . . . . . } \\
7 \cdot 2 \text { lbs. oat-straw chaff . } \\
81 \text { lbs. mangels......... }\end{array}$ & $\begin{array}{r}\mathrm{lbs} \\
3 \cdot 6 \\
3 \cdot 0 \\
3 \cdot 0 \\
6 \cdot 0 \\
10 \cdot 1\end{array}$ & $\begin{array}{l}\text { lbs: } \\
1 \cdot 38 \\
0 \cdot 42 \\
0 \cdot 19 \\
0 \cdot 10 \\
1 \cdot 30\end{array}$ & $\begin{array}{l}\text { lbs. } \\
1 \cdot 93 \\
1: 41 \\
1 \cdot 52 \\
2 \cdot h 6 \\
7 \cdot 40\end{array}$ & $\begin{array}{l}\text { lbs. } \\
3 \cdot 31 \\
1 \cdot 83 \\
1 \cdot 71 \\
2 \cdot 96 \\
8 \cdot 70\end{array}$ \\
\hline $\left.\begin{array}{r}\text { Required for sustenance } \\
\text { of } 1290 \text { lbs. live-weight }\end{array}\right\}$ & $\begin{array}{c}25 \cdot 7 \\
-\end{array}$ & $\begin{array}{l}3 \cdot 39 \\
0 \cdot 74\end{array}$ & $\begin{array}{r}15 \cdot 12 \\
9 \cdot 55\end{array}$ & $\begin{array}{l}18 \cdot 51 \\
10 \cdot 29\end{array}$ \\
\hline $\left.\begin{array}{c}\text { Required for } 30 \text { lbs. of } \\
\text { milk } \ldots \ldots \ldots \ldots \ldots \ldots\end{array}\right\}$ & - & $\begin{array}{l}2 \cdot 65 \\
1 \cdot 10\end{array}$ & $\begin{array}{l}5 \cdot 57 \\
3 \cdot 90\end{array}$ & $\begin{array}{l}8 \cdot 22 \\
5 \cdot 00\end{array}$ \\
\hline Estimated excess in food.: & 一 & $1 \cdot 55$ & $1 \cdot 67$ & $3 \cdot 22$ \\
\hline
\end{tabular}

Reckoned as starch. 
Of the $25 \frac{3}{4} \mathrm{lbs}$. of dry substance of food consumed, about $18 \frac{1}{2} \mathrm{lbs}$. are reckoned as digestible; and of the non-nitrogenous or respiratory and fat-forming portion of the food, about $9 \frac{1}{2} \mathrm{lbs}$. out of the $15 \frac{1}{8}$ are estimated to be employed in supporting the life of the animal. It is, however, probable that somewhat more than this was actually used for the purpose, as the temperature of our sheds would be lower than in the cases of the German experiments above referred to. Thus, whilst for the mere sustenance of the cow the demand upon the non-nitrogenous constituents of the food is very large, the requirement for the nitrogenous constituents is small.

In the case of all the foods except the roots, only that portion of the nitrogenous and non-nitrogenous constituents which is estimated to be digestible is entered in the table; but as regards the mangels all the constituents are included, as the German calculations do not make any allowance for indigestible matter in their case. It is generally assumed, however, that it is only those compounds which contain nitrogen in the form of albuminoids that are competent to form flesh and the nitrogenous compounds of milk; whilst it is certain that a very large proportion of the nitrogen in roots is not in that form. In connection with ensilage this subject becomes of great importance, as there seems to be no doubt that during the fermentation much of the albuminoid matter is destroyed.

It will be observed that of the $10.1 \mathrm{lbs}$. of dry substance of the mangels, $1 \cdot 3 \mathrm{lb}$. is given as digestible nitrogenous matter; but of this total quantity as little as one-fifth may, and pretty certainly not more than two-fifths would, consist of albuminoids. Out of the $10^{\circ} 1 \mathrm{lbs}$. of total dry substance, $7 \cdot 4 \mathrm{lbs}$, , or about 74 per cent., are recorded as digestible non-nitrogenous, or respiratory and fat-forming matter. We thus see what constitutes the great value of the root-crops. It is the fact that they furnish the essential respiratory constituents of food in very large quantities; though, even when grown under very favourable conditions of soil and season, they are not adapted for fattening, unless used in conjunction with other foods. For the purpose of mere sustenance however-as, for instance, in the case of cows which are out of milk, but are kept in warm yards or sheds-roots are a very suitable food used with straw chaff.

It may here be mentioned incidentally, that the loss of lambs born dead, which is often attributed to the manure used for the roots, is more probably due to the want of sufficient albuminoids in the roots. It should be further understood that while the nitrogenous constituents of the food can be used by the animals for respiratory purposes, the non-nitrogenous constituents cannot be used for the production of albuminoids; and as a certain amount of albuminoids is essential, if the food is deficient in them the animal must wastefully consume the 
non-nitrogenous substances in excess in order to obtain enough of the albuminoids.

The quantities given in the table are calculated for a cow weighing 1290 lbs.; but if as many sheep as would represent an equivalent weight were substituted for the cow, the amount of sustenance food necessary to keep them without increasing or losing weight, would be considerably higher; partly because more surface would be exposed to the cold, and partly because there is always more or less growth of wool.

Out of the $15 \frac{1}{8} \mathrm{lbs}$. of total digestible non-nitrogenous, or respiratory and fat-forming matter in the food, the home produce of the farm furnished rather more than $11 \frac{3}{4} \mathrm{lbs}$, and the purchased cake and bran about $3 \frac{1}{3} \mathrm{lbs}$; ; and as the sustenance of the animal is reckoned to require only about $9 \frac{1}{2} \mathrm{lbs}$., there remains a surplus of $2 \frac{1}{4} \mathrm{Jbs}$. of the home produce, and all the respiratory constituents of the purchased food, available for the production of milk or increase. Instead of the $9 \frac{1}{2}$ lbs. required by the cow for sustenance, sheep of the same weight would probably require the whole of the digestible non-nitrogenuus substance of the farm-produce for sustenance alone; and they would be entirely dependent upon the purchased food for increase in liveweight.

It has been shown that the food requirements of a cow for the purposes of sustenance only, are very small so far as the nitrogenous constituents are concerned, but large for the respiratory, or nonnitrogenous matters. For a cow yielding $30 \mathrm{lbs}$. (nearly 3 gallons) of milk per day, however, the requirement for the nitrogenous constituents is very much greater. Foods which are rich in nitrogen, such as oil-cakes and leguminous seeds, are therefore specially adapted for the production of milk.

It is somewhat remarkable that the composition of bran, which has a special value in the eyes of all dairy-men, bears a very close relation to that of milk in the proportion of the digestible nitrogenous and non-nitrogenous constituents, as will be seen in the following table:-

$\begin{array}{rlc} & \begin{array}{c}\text { Digestible } \\ \text { nitrogenous } \\ \text { matter. }\end{array} & \begin{array}{c}\text { Digestible } \\ \text { non-nitrogenous } \\ \text { matter. }\end{array} \\ 3 \frac{1}{2} \text { lbs. of bran will supply .... } & 0.42 & 1 \cdot 41 \\ 11 \frac{1}{2} \quad \text {, of milk will contain.... } & 0.42 & 1.49\end{array}$

Table IX (p. 31) shows that, in the 4 lbs. of cake and $3 \frac{1}{2}$ lbs. of bran, which were daily supplied to the cows, the total digestible constituents would be approximately the same as those required to produce the $30 \mathrm{lbs}$. of milk; but the nitrogenous would be in excess, and the nonnitrogenous in abont corresponding deficiency. As, however, the 
amount of milk varies very much, owing to the difference in the milkyielding capacity of different cows, and as every cow, whatever its capacity may be, has a maximum yield which is followed by an almost daily decline, it appeared desirable, while the ensilage experiments were going on, that the cake and bran, which obviously contributed so largely to the production of the milk, should be supplied to each cow somewhat in proportion to its yield.

The following Table (X) shows, not only how rery large, but how very variable, may be the amounts of total solid matter, nitrogenous matter, fat, \&c., in the milk yielded by different cows, or eren by the same cow at different periods between calving and dryness. For comparison there is also given, the estimated composition of the increase in live-weight of a fattening ox weighing $1000 \mathrm{lbs}$., the amount of which increase would frequently be only about $10 \mathrm{lbs}$, and would rarely exceed $15 \mathrm{lbs}$. per week.

The table shows the amounts of the various solid constituents in the milk yielded per week by cows giving respectively $4,8,12,16$, and 20 quarts per day $=7,14,21,28$, and 35 gällons per head per week, assuming the milk to contain 12.50 per cent. of total solids; consisting of 3.65 per cent. albuminoids, 3.50 per cent. butter-fat, 4.60 per cent. sugar, and 0.75 per cent. mineral matter. The table also shows; the estimated constituents in the weekly increase in liveweight of a fattening ox weighing 1000 lbs. :-

TABLE X.

\begin{tabular}{|c|c|c|c|c|c|}
\hline $\begin{array}{l}\text { Milk per week (one } \\
\text { gallon reckoned to } \\
\text { weigh } 10.33 \text { lbs.). }\end{array}$ & $\begin{array}{l}\text { Total } \\
\text { solid } \\
\text { matter. }\end{array}$ & $\begin{array}{l}\text { Nitrogen- } \\
\text { ous sub- } \\
\text { stance. }\end{array}$ & Fat. & $\begin{array}{l}\text { Non-nitro- } \\
\text { genous } \\
\text { substance } \\
\text { not fat. }\end{array}$ & $\begin{array}{l}\text { Mineral } \\
\text { matter. }\end{array}$ \\
\hline 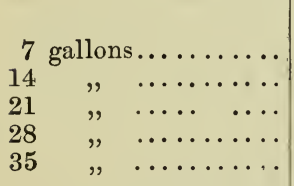 & $\begin{array}{l}\text { lbs. } \\
9 \cdot 04 \\
18 \cdot 08 \\
27 \cdot 12 \\
36 \cdot 16 \\
45 \cdot 20\end{array}$ & $\begin{array}{c}\text { lbs. } \\
2 \cdot 64 \\
5 \cdot 28 \\
7 \cdot 92 \\
10 \cdot 56 \\
13 \cdot 20\end{array}$ & $\begin{array}{r}\text { lbs. } \\
2 \cdot 53 \\
5 \cdot 06 \\
7 \cdot 59 \\
10 \cdot 12 \\
12 \cdot 65\end{array}$ & $\begin{array}{l}\text { lbs. } \\
3 \cdot 33 \\
6 \cdot 66 \\
9 \cdot 99 \\
13 \cdot 32 \\
16 \cdot 65\end{array}$ & $\begin{array}{l}\text { lbs. } \\
0 \cdot 54 \\
1 \cdot 08 \\
1 \cdot 62 \\
2 \cdot 16 \\
2 \cdot 70\end{array}$ \\
\hline $\begin{array}{r}10 \text { lbs. increase in live- } \\
\text { weight........... } \\
15 \text { lbs. increase in live- } \\
\text { weight........... }\end{array}$ & $7 \cdot 25$ & $0 \cdot 75$ & $6 \cdot 35$ & - & $0 \cdot 15$ \\
\hline
\end{tabular}

It may be observed that whilst the meat-produciug power of an ox is confined within comparatively narrow limits, the milk-producing capacity of a cow has a very wide range. Another very remarkable fact is the extremely small amount of both nitrogenous and mineral 
matter which is stored up in the increase of an ox, compared with that carried off in the milk of a cow. Hence, a dairy, where milk is exported, is very exhausting.

It is evident that there is far more scope for economy in the regulation of the diet of a cow producing milk, than in that of a fattening ox. During the period in which an ox advances from the store condition to fatness, at an average rate of increase which may be estimated at from 1 to $1 \frac{1}{2}$ per cent. of its live-weight per week, a cow may be yielding 5 gallons of milk per day at one time, and at another less than one-fourth of that quantity.

Starting with the fact that the two lots of 20 cows each, which were under experiment, were receiving, per head per day, 4 lbs. of cake, and $3 \frac{1}{2}$ lbs. bran, with a fixed amount of chaff, and, in addition, in one case silage, and in the other roots, and were yielding an average of 28 libs. of milk per head per day, it was decided that whilst each lot of 20 cows should continue to receive the total of $80 \mathrm{lbs}$. of cake daily, the amount should be so apportioned among the 20 that each cow should receive more or less than 4 lbs. daily, accordingly as its yield during the preceding week averaged more, or less, than 28 lbs. of milk per day. The average yield of milk of each cow was, therefore, made up at the end of the week; and, for the succeeding week, 4 lbs. of cake were given to every cow which had yielded 28 lbs. of milk daily : and to each cow which yielded more or less than this quantity, the amount of cake was increased, or reduced, in the proportion of $\frac{1}{4} \mathrm{lb}$. of cake for each $2 \mathrm{lbs}$. of milk yielded more or less than $28 \mathrm{lbs}$.

Thus, if a cow yielded 50 lbs. of milk per day (nearly 5 gallons), that is $22 \mathrm{lbs}$. more than the standard amount of $28 \mathrm{lbs}$., it received an extra allowance of $2 \frac{3}{4}$ lbs. of cake, or in all $6 \frac{3}{4} \mathrm{lbs}$. per day; if it yielded $40 \mathrm{lbs}$. (nearly 4 gallons) or $12 \mathrm{lbs}$. in excess of the average, it received $1 \frac{1}{2} \mathrm{lb}$. cake extra, or a total of $5 \frac{1}{2} \mathrm{lbs}$; if $30 \mathrm{lbs}$., or $2 \mathrm{lbs}$. extra, in all $4 \frac{1}{4} \mathrm{lbs}$. cake; if only $20 \mathrm{lbs}$., or $8 \mathrm{lbs}$. deficiency, only $3 \mathrm{lbs}$. of cake; or if only $10 \mathrm{lbs}$., or $18 \mathrm{lbs}$. deficiency, it received $2 \frac{1}{4} \mathrm{lbs}$. less cake, or in all only $1 \frac{\dot{3}}{4} \mathrm{lb}$., and so on.

We cannot at present discuss the results of this experiment; but anyone who looks at the table showing the difference between the amount of solid matter contained in 7 gallons and in 35 gallons of milk, will admit that, without some regulation of the diet, one of two things must take place. Either the yield of some cows must be stinted for want of sufficient food, or others must be receiving food which cannot be turned to profitable account. The highest average yield of milk of any cow during our experiments was 51 lbs., or nearly 20 quarts per day, whilst several were yielding, at the same time, not much more than one-fifth of this quantity.

It is no unusual thing to give fattening oxen $15 \mathrm{lbs}$. to $18 \mathrm{lbs}$. of 
cake and corn per day. An ox receiving this quantity of food must be consuming a very large amount of nitrogenous substance, of which but a very small percentage is found in the increase in live-weight. A certain amount of that which is digested may be employed in the production of fat, the nitrogen being found in the urine in soluble compounds. In this form, however, the nitrogen nitrifies so rapidly in the soil, that it has little more permanence as manure than that in a salt of ammonia, or in nitrate of soda.

On the other hand, the bulk of the manure of a fattening ox possesses a durability which is well established in practice. Indeed, it may be considered that "condition;" or " unexhausted fertility" of a soil, is chiefly due to the constituents of the food which pass, with but little change, in the solid excrements of the fattening animals; but partly also to those in the litter. To accumulate nitrogen in the soil, it must be in combination with carbon. In a field where we grow barley continuously, manured with rape cake, although the cake largely increases the crop, a residue still accumulates in the soil, sufficient to be measurable by analysis, and so to establish a claim for unexhausted fertility.

\section{7.-Preliminary Experiments with Mílihing Cows.}

In the beginning of February, 1884, one of the laboratory staff was instructed to take the weight of each cow's milk, morning and evening, and to ascertain the amount of food consumed. This was before a brick of the silos was laid, but in anticipation of experiments which it was intended to carry out in the following winter.

From the 4th of February to the 9th March, the average yield of milk per cow per day was 29 lbs. 13 oz., and the average consumption of food per head per day was estimated to be as follows :-

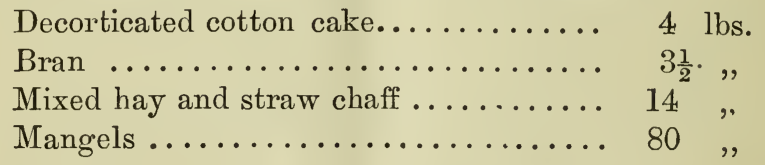

The fluctuations in the average daily yield of milk were very small, the highest of any one day being just below $32 \mathrm{lbs}$, and the lowest a little above $27 \mathrm{lbs}$. The weights of food were not, however, taken with sufficient accuracy to be altogether reliable, as will be evident from the results obtained in the following month, when it was found that between March 10th and April 7th the average yield of milk was $30 \mathrm{lbs} .5 \mathrm{oz}$. The same amounts of cake and bran were consumed, but of chaff it was found, on accurate weighing (instead of measuring), that the consumption amounted to only $10 \frac{1}{2}$ lbs. per cow, 
or $3 \frac{1}{2}$ lbs. per head per day less than the amount estimated to be given in the previous month. The amount of dry substance of food consumed per cow daily was now $25 \frac{1}{4} \mathrm{lbs}$., whilst the figures for the previous month would give $28 \frac{1}{4} \mathrm{lbs}$; ; but it is probable that not more than from $25 \mathrm{lbs}$. to $26 \mathrm{lbs}$. of dry substance was really consumed.

The grass was so forward on April the 8th, that the cows were turned out from 11 o'clock to 3 o'clock each day. This was continued until the 17th, during which time they had the same cake and bran as before, but only about half the amount of chaff and rather less mangels. On April 17 they were turned out altogether; but continued to have the same quantity of cake; the bran, chaff, and mangels, being gradually reduced; the two latter being stopped altogether in the middle, and the bran at the end of May. The average yield of milk only increased slightly, the amount being $31 \frac{3}{4} \mathrm{lbs}$. as against $30 \frac{1}{4} \mathrm{lbs}$; and the highest increase during the summer was to $35 \mathrm{lbs} .3 \mathrm{oz}$. in the week ending May 17th.

It does not appear that, if cows have been well fed during the winter, any large increase of milk is obtained when they are turned out to grass ; and later on, when the weather became hot and dry, the milk fell off very much, the flies having been very troublesome during part of the time. With the exception of the cotton cake, 4 lbs. of which were given to each cow daily, no record of food consumed was possible until the cows again went into their winter quarters in November, but in the meantime the milk was carefully weighed.

\section{8.-Plan and Arrangement of the Experiments with Milking Cows.}

In the beginning of December, 1884, 48 cows were in milk, 40 standing in one house-20 facing the other 20-the food being supplied from a gangway down the centre. We proposed to try only two experiments; and after much trouble in calculation, and finding it hopeless to match each individual cow in one lot with one in the other which had been approximately the same length of time in milk, and was yielding the same amount of milk, it was finally decided to select from the herd two lots, of 20 each, which should agree as nearly as possible in the following conditions: (1) the average number of weeks since calving; (2) the average yield of milk. This involved the shifting of some of the cows-a proceeding which they strongly resented. Eventually two lots of 20 each were selected, which gave between 14 and 15 weeks as the average date since calving, and an average daily yield of milk of between $30 \mathrm{lbs}$. and $31 \mathrm{lbs}$. during the preceding 10 weeks; or less, if they had not been in milk so long.

Of course these averages were made up of very great differences, both in the length of time since calving, and in the yield of milk; 
but such is the case in all herds where it is of importance to obtain, as nearly as possible, an uniform supply of milk all the year round. As the experiments were to go on for some months, it was evident that, in both lots, some cows would become dry, and would have to be replaced by others which had recently calved. Still it was considered that results obtained under these circumstances were far more likely to be trustworthy than if the experiment had been made on individual, or on a very few, cows.

Although a certain amount of interest attaches to the substitution of silage for hay, it will be admitted by every practical farmer, that the real value of silage must greatly depend upon its capability of wholly, or at any rate largely, superseding root-crops. To those who are out of the reach of brewer's grains, roots are the only succulent food available for fully half the year; and it is tolerably evident that, without some succulent food, neither meat nor milk can be produced profitably during the winter months.

As already shown, in the experiments with fattening oxen, cloversilage was tried against a mixture of clover-hay-chaff and swedes; but in the experiments with milking cows, now to be described, the comparison is limited to the trial of silaged crops against mangels.

In arranging comparative feeding experiments, it is always desirable that those foods which are not the subject of comparison should be the same for the different lots of animals. Silage, and especially that made from red clover, with which we began our experiment, differs from roots in some important respects. It contains a much higher percentage of dry substance, its dry substance contains a considerably higher proportion of albuminoid compounds, and also very much more indigestible woody fibre. It was impossible, therefore, so to arrange the two rations as to supply exactly the same constituents in each; and it was decided that equal quantities of dry substance should be given in the silage, and in the mangels.

The following amounts of other foods were allotted-per head per day to each of the 40 cows :-

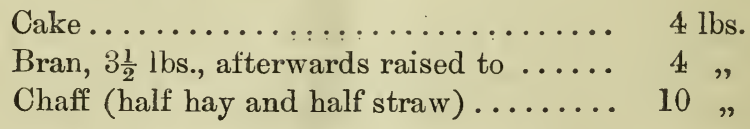

Thus far the same foods were given to each lot; but, in addition, one lot received, per head per day, at first $42 \mathrm{lbs}$. of clover-silage, gradually raised to $50 \mathrm{lbs}$., and the other lot at first $75 \mathrm{lbs}$. of mangels, gradually increased to 90 lbs., as the silage given to the others was increased, and it was found that lower down in the pit it contained a higher percentage of dry matter. Most of the cows took to the silage readily, though a few had a distinct aversion to it, and in order not to 
influence their yield of milk injuriously these were supplied with a limited quantity of mangels as well as silage, the former being reduced and the latter increased until their repugnance to the food had ceased.

Two or three weeks elapsed before the disturbance caused by the necessary changes in the position of some of the cows, and in the alteration of their food, was overcome; and it was not until the 24th of December that the animals were weighed.

\section{9.-The Results of the Experiments with Milking Cows.}

Table XI (p. 41) shows the average amounts of food consumed per head per day, by each lot of 20 cows, within each of the 13 weeks of the experimental period.

Table XII (pp. 42-3) shows, for each of the 20 cows receiving clover-silage, and Table XIII (pp. 44-5), for each of the 20 receiving mangels, the dates of calving, the average yield of milk per day prior to the commencement of the experiment, and the average yield during each of the 13 weeks of the experimental period. They also show, the average yield per day, and the total yield, both in lbs. and gallons, of each cow, over the whole of the experimental period.

Milking cows are exceedingly sensitive to change in anything they have been accustomed to ; and after the few necessary transpositions of the animals had been made in accordance with the allotments, and the experiment had fairly commenced, they were treated exactly as if they had not been under experiment at all; the only difference in the management being that both the food and the milk were carefully weighed. Several of the cows of each lot became dry during the experiment; and they were replaced by others, as explained in the foot notes to Tables XII and XIII. The results proved that the new cows were not all equally good milkers; but the differences are to some extent neutralised by the large number of animals in each lot.

Table XI (p. 41), relating to the food, shows that during the first few weeks, until the animals had become accustomed to the silage, a small quantity of mangels was given with it; and this was done again towards the end of the experiment, in the case of a few cows which did not consume all their silage, when it was found that, with the admixture of a small quantity of rnangels, they generally consumed their silage also. Most of the animals, however, took to the silage quite readily.

At page 35, it was stated that each lot of 20 cows received the same total amount of cake and bran, but that, after a time, first the cake, and afterwards the bran also, were allotted to the individual cows within each lot in proportion to their yield of milk. That is to 
say, instead of each cow receiving $4 \mathrm{lbs}$. of cake, and $3 \frac{1}{2} \mathrm{lbs}$. of bran, it received more or less than these quantities, in proportion as its yield of milk was more or less than the average of the whole lot. We shall consider the results of this apportionment of the purchased foods according to the yield of milk at some future time.

Tables XII and XIII show that, over the whole experimental period of 13 weeks, the average yield of milk of the cows receiving clover-silage was 25 lbs. 12 ozs. per head per day, against 27 lbs. 5 ozs., yielded by the cows receiving mangels. This corresponds to a difference over the whole period of 14 gallons per head, or of 281 gallons in the lot of $20 \mathrm{cows}$, in farour of those receiving mangels.

It is probable that part of this difference was due to the fact that two of the cows brought into the mangel lot during the progress of the experiment (Nos. 21 and 40), turned out to be much better milkers than any two brought into the silage lot. But it is probable that it was also in part due to the more succulent mangels being a more appropriate addition to the dry food for milking cows, than so much silage, which contained nearly twice as high a percentage of dry substance as the mangels. That this was so would appear from the fact that the cows on the silage drank an average of about $1 \frac{3}{4}$ gallon more water per head per day than those on the mangels.

Upon the whole the evidence points to the conclusion that if a portion of the dry matter of the clover-silage, say one-fifth or more, had been replaced by a corresponding amount in mangels, not only would some of the cows have consumed the silage better, but such a mixture would doubtless have been more appropriate for milk-yielding. It was feared, however, that if a mixture of the two foods to be compared were given, the results might not be sufficiently distinct. It may be added that the general impression among the attendants was that the cows on the clover-silage showed more tendency to fatten than the others; whilst, as a matter of fact, they did give rather more increase in live-weight. To this point we shall recur further on.

It will be seen that the anticipation we expressed that there would be considerable difficulty in getting strictly comparable results in experiments with dairy cows has been fully realised. But, as the whole of the data are now before the reader, he can form his own conclusions respecting them. 


\section{EXPERIMENTS WITH COWS.}

Table XI.-Average Food Consumed per Head per Day.

13 Weeks ; December 14, 1884, to March 14, 1885.

\begin{tabular}{|c|c|c|c|c|c|c|}
\hline \multirow[b]{2}{*}{ Week ending } & \multicolumn{5}{|c|}{ Average food given per head per day. } & \multirow{2}{*}{$\begin{array}{c}\text { Total food } \\
\text { weighed } \\
\text { off. }\end{array}$} \\
\hline & Cake.* & Bran. & Chaff. & $\begin{array}{l}\text { L over- } \\
\text { silage. } \dagger\end{array}$ & Mangels. $\ddagger$ & \\
\hline \multicolumn{7}{|c|}{ Lot 1.- 20 Cows; Experimental Food-Clover-silage. } \\
\hline $1884-5$ & lbs. & lbs. & lbs. & lbs. & lbs. & lbs. \\
\hline Dec. 20$] \quad \ldots \ldots \ldots$ & 4 & $3 \frac{1}{2}$ & $6 \frac{3}{4}$ & $42 \frac{1}{8}$ & $13 \frac{3}{4}$ & $410 \frac{1}{2}$ \\
\hline$" \quad 27\} \S \ldots \ldots \ldots$ & 4 & $3 \frac{1}{2}$ & $9 \frac{1}{8}$ & $44 \frac{3}{8}$ & $8 \frac{5}{8}$ & 0 \\
\hline Jan. 3$] \quad \ldots \ldots \ldots$ & 4 & $3 \frac{1}{2}$ & $10^{\circ}$ & $46 \frac{7}{8}$ & $4 \frac{1}{4}$ & 0 \\
\hline, $10 \ldots \ldots \ldots \ldots$ & 4 & $3 \frac{1}{2}$ & 10 & $48 \frac{5}{8}$ & (3) $13 \frac{7}{8}$ & 0 \\
\hline$" 17 \ldots \ldots \ldots$ & 4 & $3 \frac{1}{2}$ & 10 & 50 & 0 & 0 \\
\hline 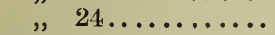 & 4 & $3 \frac{1}{2}$ & 10 & 50 & 0 & 0 \\
\hline , $31 \ldots \ldots \ldots \ldots$ & 4 & $3 \frac{1}{2}$ & 10 & 50 & 0 & 0 \\
\hline Feb. $\quad 7 \ldots \ldots \ldots$ & 4 & $3 \frac{1}{2}$ & 10 & 50 & 0 & 0 \\
\hline , $14 \ldots \ldots \ldots \ldots$ & 4 & $3 \frac{1}{2}$ & 10 & 50 & 0 & 0 \\
\hline,$\quad 21 \ldots \ldots \ldots \ldots$ & 4 & $3 \frac{1}{2}$ & 10 & 50 & (1) & 0 \\
\hline$" 28 \ldots \ldots \ldots \ldots$ & 4 & $3 \frac{8}{4}$ & 10 & 50 & (2) & 415 \\
\hline Mar. $7 \ldots \ldots \ldots$ & 4 & $4^{4}$ & 10 & 50 & (2) & 307 \\
\hline, $14 \ldots \ldots \ldots \ldots$ & 4 & 4 & 10 & 50 & 0 & 353 \\
\hline Per head per day.... & - & - & - & 一 & - & $0 \frac{3}{4}$ \\
\hline
\end{tabular}

Lot 2.-20 Cows; Experimental Food-Mangels.

\begin{tabular}{|c|c|c|c|c|c|c|}
\hline $1884-5$ & lbs. & lbs. & lbs. & lbs. & lbs. & lbs. \\
\hline Dec. 20$\} \|$....... & 4 & $3 \frac{1}{2}$ & 11 & 一 & 75 & - \\
\hline$" 27\} \| \ldots \ldots$ & 4 & $3 \frac{1}{2}$ & $10 \frac{7}{8}$ & - & $75 \frac{3}{4}$ & - \\
\hline Jan. $\quad 3 . . . . . . . .$. & 4 & $3 \frac{1}{2}$ & 10 & 二 & 80 & 一 \\
\hline$" 10 \ldots \ldots \ldots \ldots$ & 4 & $3 \frac{1}{2}$ & 10 & - & 80 & - \\
\hline $17 \ldots \ldots \ldots \ldots$ & 4 & $3 \frac{1}{2}$ & 10 & - & $82 \frac{7}{8}$ & 一 \\
\hline $24 \ldots \ldots \ldots \ldots$ & 4 & $3 \frac{1}{2}$ & 10 & - & 90 & - \\
\hline$" 31 \ldots \ldots \ldots \ldots$ & 4 & $3 \frac{1}{2}$ & 10 & - & 90 & - \\
\hline Feb. $\quad 7 \ldots \ldots \ldots \ldots$ & 4 & $3 \frac{1}{2}$ & 10 & - & 90 & - \\
\hline,$\quad 14 \ldots \ldots \ldots \ldots$ & 4 & $3 \frac{1}{2}$ & 10 & - & 90 & - \\
\hline $21 . \ldots \ldots \ldots \ldots$ & 4 & $3 \frac{1}{2}$ & 10 & - & 90 & - \\
\hline $28 \ldots \ldots \ldots \ldots$ & 4 & $3 \frac{3}{4}$ & 10 & - & 90 & - \\
\hline Mar. $7 \ldots \ldots \ldots \ldots$ & 4 & 4 & 10 & - & 90 & - \\
\hline $14 \ldots \ldots \ldots \ldots$ & 4 & 4 & 10 & - & 90 & 一 \\
\hline Per head per day.... & - & - & 一 & - & - & - \\
\hline
\end{tabular}

* December 14 to January 5, half linseed, and half decorticated cotton-cake ; afterwards decorticated cotton-cake only.

+ Second-crop clover-silage, December 14 to January 10; afterwards first-crop clover-silage.

‡ First three weeks some mangels were supplied to all the silage-fed cows; the figures in parentheses show the number of cows receiving mangels at other periods.

$\S$ Averages for 19 cows only; cow No. 19 various foods.

II Averages for 19 cows only; cow No. 35 various foods. 
EXPERIMENTS

TABLE XII.-YieLd OF MilK

Lot 1.-20 Cows.

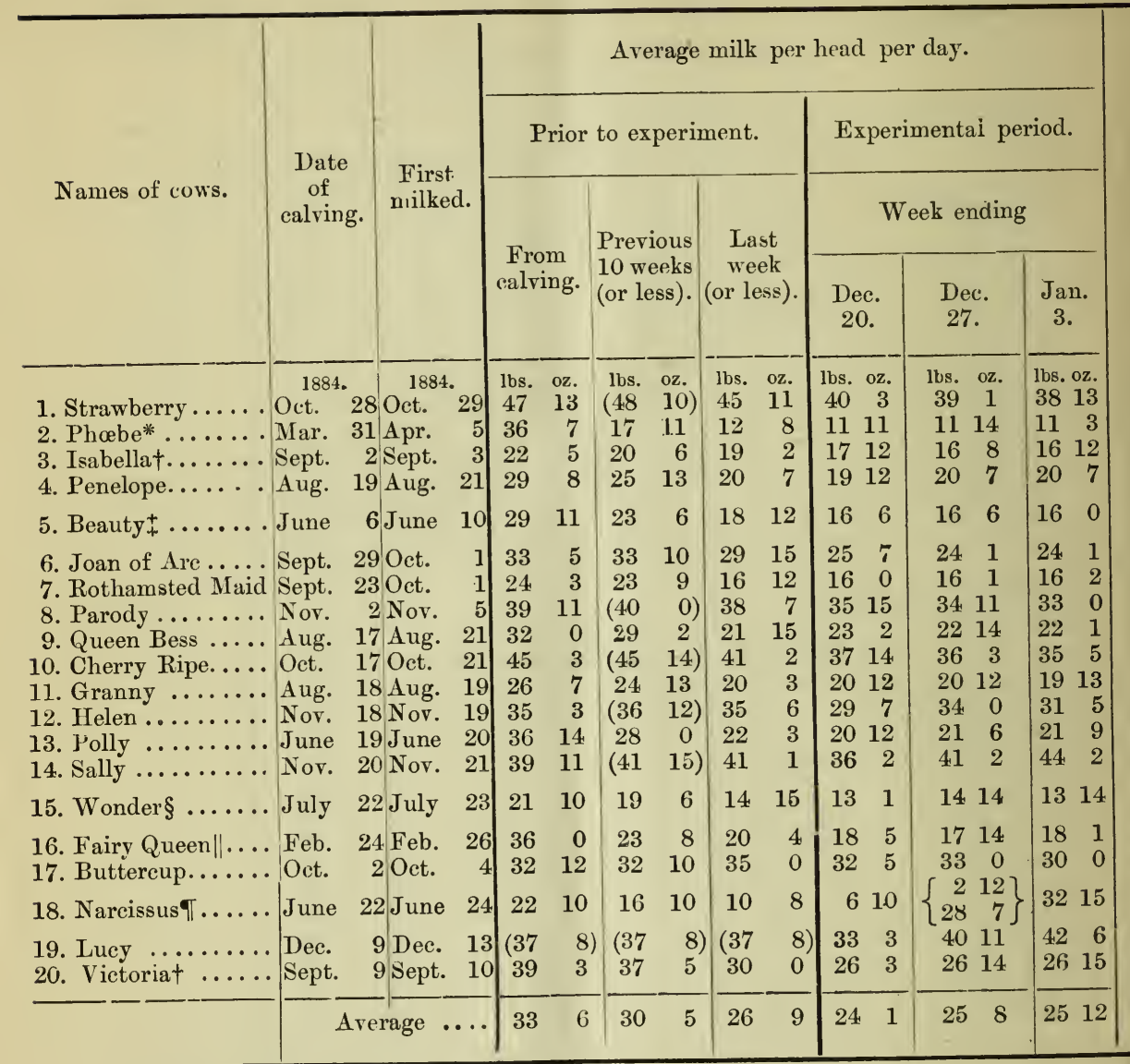

* Replaced January 11th, by Ann, calved January 3rd.

+ Bought as newly-calved at this date; exact date of calving not known.

+ Replaced February 5th, by Gypsy, calved January 30th; Gypsy (ill) replaced February 16th, by Rosemary, calved February 12 th. 


\section{WITH COWS.}

per Head per Day (lis).

Experimental Food-Clover-silage.

\begin{tabular}{|c|c|c|c|c|c|c|c|c|c|c|c|c|}
\hline \multicolumn{10}{|c|}{ Average milk per head per day. } & \multirow{2}{*}{\multicolumn{3}{|c|}{$\begin{array}{l}\text { Summary for ex- } \\
\text { perimental period. } \\
13 \text { weeks, } \\
\text { Dec. 14-Mar. } 14 .\end{array}$}} \\
\hline \multicolumn{10}{|c|}{ Experimental period. } & & & \\
\hline \multicolumn{10}{|c|}{ Week ending } & \multirow{2}{*}{\begin{tabular}{|l} 
Aver- \\
age \\
per \\
day.
\end{tabular}} & \multirow{2}{*}{\multicolumn{2}{|c|}{ Total yield. }} \\
\hline $\begin{array}{r}\text { Jan. } \\
10 .\end{array}$ & $\begin{array}{c}\text { Jan. } \\
17 .\end{array}$ & $\begin{array}{c}\text { Jan. } \\
24 .\end{array}$ & $\begin{array}{c}\text { Jan. } \\
31 .\end{array}$ & $\begin{array}{c}\text { Feb. } \\
7 .\end{array}$ & $\begin{array}{c}\text { Feb. } \\
14 .\end{array}$ & $\begin{array}{c}\text { Feb. } \\
21 .\end{array}$ & $\begin{array}{c}\text { Feb. } \\
28 .\end{array}$ & $\begin{array}{c}\text { Mar. } \\
7 .\end{array}$ & $\begin{array}{c}\text { Mar. } \\
14 .\end{array}$ & & & \\
\hline $\begin{array}{l}\text { lbs. oz. } \\
36\end{array}$ & $\left|\begin{array}{cc}\text { lbs. } & \text { oz. } \\
36 & 13\end{array}\right|$ & $\begin{array}{ll}\text { lbs. } & \text { oz. } \\
35 & 6\end{array}$ & $\begin{array}{ll}\text { lbs. oz. } \\
36\end{array}$ & ; $\begin{array}{c}\text { lbs. oz. } \\
36\end{array}$ & lbs. oz. & $\begin{array}{l}\text { lbs. oz. } \\
34 \text { 10 }\end{array}$ & $\begin{array}{l}\text { lbs. oz. } \\
33 \quad 7\end{array}$ & lbs. oz. & & lbs. oz. & los. & \\
\hline 105 & $35 \quad 4$ & $\begin{array}{ll}37 & 1\end{array}$ & 3911 & $38 \quad 6$ & 381 & $36 \quad 2$ & $\begin{array}{ll}00 \\
36 & 6\end{array}$ & $\left|\begin{array}{rr}33 & 4 \\
35 & 13\end{array}\right|$ & $\begin{array}{rr}31 & 11 \\
33 & 3\end{array}$ & $\left|\begin{array}{ll}35 & 15 \\
28 & 14\end{array}\right|$ & $\left|\begin{array}{l}3271 \frac{3}{4} \\
2624 \frac{7}{7}\end{array}\right|$ & $\begin{array}{l}317 \\
254\end{array}$ \\
\hline $16 \quad 6$ & $\begin{array}{ll}16 & 7\end{array}$ & $\begin{array}{ll}15 & 11\end{array}$ & $\begin{array}{ll}15 & 11\end{array}$ & 159 & $\begin{array}{ll}15 & 14\end{array}$ & 158 & 1512 & $\begin{array}{ll}15 & 12\end{array}$ & 154 & $\begin{array}{rr}0 & 1\end{array} \mid$ & & \\
\hline $\begin{array}{ll}19 & 5\end{array}$ & $\begin{array}{ll}19 & 11\end{array}$ & 196 & 198 & $\begin{array}{ll}19 & 7 \\
\end{array}$ & 190 & 188 & 1713 & 1515 & 158 & $18 \quad 13$ & $\begin{array}{l}1712 \frac{1}{2} \\
1\end{array}$ & 166 \\
\hline 158 & $\begin{array}{ll}14 & 1\end{array} \mid$ & 138 & 1212 & $\left\{\begin{array}{rr}12 & 1 \\
14 & 11\end{array}\right\}$ & 13 & $\left\{\begin{array}{ll}17 & 15 \\
28 & 15\end{array}\right\}$ & 3213 & $33 \quad 4$ & 334 & 1911 & 1794 & 174 \\
\hline $\begin{array}{ll}21 & 12\end{array}$ & $21 \quad 8$ & 2111 & 210 & $\begin{array}{ll}1 \\
19 & 12\end{array}$ & 1915 & 1915 & & 1813 & 18 & 213 & $1926 \frac{7}{8}$ & 186 \\
\hline $\begin{array}{ll}15 & 8 \\
29 & 0\end{array}$ & $\begin{array}{ll}15 & 5\end{array}$ & 1413 & 142 & $\begin{array}{ll}13 & 15\end{array}$ & & 1215 & 12 & 1114 & $\begin{array}{ll}11 & 4\end{array}$ & $14 \quad 2$ & $1287 \frac{3}{4}$ & 125 \\
\hline & $\begin{array}{rr}33 & \tilde{3} \\
21 & 13\end{array} \mid$ & $\begin{array}{lr}33 & 8\end{array}$ & $\begin{array}{ll}33 & 3\end{array}$ & 338 & 320 & $\begin{array}{ll}31 & 7\end{array}$ & $\begin{array}{ll}31 & 0\end{array}$ & 306 & 2913 & 3210 & $2970 \frac{1}{8}$ & 287 \\
\hline $\begin{array}{rr}22 & 3 \\
33 & 14\end{array}$ & $\left|\begin{array}{rr}21 & 13 \\
33 & 9\end{array}\right|$ & $\begin{array}{ll}20 & 11 \\
39 & 11\end{array}$ & 1914 & 1815 & $\left|\begin{array}{ll}18 & 1\end{array}\right|$ & 1615 & 1515 & 14.13 & $\begin{array}{ll}12 & 12\end{array}$ & 194 & 17 & 169 \\
\hline $\begin{array}{ll}33 & 14 \\
18 & 13\end{array}$ & $\left|\begin{array}{rr}33 & 9 \\
17 & 11\end{array}\right|$ & & 3213 & $\begin{array}{ll}32 & 0 \\
18 & 5\end{array}$ & $\begin{array}{ll}31 & 12\end{array}$ & $\begin{array}{ll}31 & 2\end{array}$ & $31 \quad 6$ & $\begin{array}{ll}31 & 6\end{array}$ & $\begin{array}{ll}31 & 2\end{array}$ & 33 & & \\
\hline $\begin{array}{rr}18 & 13 \\
32 & 4\end{array}$ & $\mid \begin{array}{rr}17 & 11 \\
31 & 6\end{array}$ & $\left|\begin{array}{rr}16 & 15 \\
29 & 8\end{array}\right|$ & 1710 & $\begin{array}{ll}18 & 5 \\
28 & 8\end{array}$ & 1615 & 155 & 1310 & 1415 & $14 \quad 2$ & 17 & $1579 \frac{7}{2}$ & 15 \\
\hline $\begin{array}{cc}20 & 11\end{array}$ & $\begin{array}{ll}21 & 3\end{array}$ & $\left|\begin{array}{rr}29 & 8 \\
20 & 15\end{array}\right|$ & $\begin{array}{rr}27 & 12 \\
20 & 5\end{array}$ & $\begin{array}{lr}28 & 8 \\
20 & 10\end{array} \mid$ & $\begin{array}{ll}27 & 11 \\
20\end{array}$ & $\begin{array}{ll}28 & 9 \\
20 & 4\end{array}$ & 2611 & $\begin{array}{lll}26 & 14\end{array}$ & $\begin{array}{ll}25 & 2\end{array}$ & 29 & $2653 \frac{1}{8}$ & 25 \\
\hline 4210 & $\mid \begin{array}{ll}44 & 5\end{array}$ & $44 \quad 0$ & 4415 & $\begin{array}{lll}20 & 10 \\
45 & 10\end{array}$ & $\left|\begin{array}{ll}20 & 3 \\
46 & 2\end{array}\right|$ & $\mid \begin{array}{rr}20 & 4 \\
46 & 13\end{array}$ & $\begin{array}{ll}20 & 1 \\
44 & 1\end{array}$ & $\begin{array}{ll}19 & 14\end{array}$ & $\begin{array}{ll}19 & 7\end{array}$ & $20 \quad 9$ & & \\
\hline $\begin{array}{ll}13 & 7\end{array}$ & $\begin{array}{ll}12 & 13\end{array}$ & $\begin{array}{ll}12 & 2\end{array}$ & 1212 & $\begin{array}{ll}13 & 9\end{array}$ & 134 & $\begin{array}{ll}13 & 10\end{array}$ & $\left\{\begin{array}{rl}44 & 1 \\
14 & 1\end{array}\right\}$ & $\begin{array}{lll}44 & 10\end{array}$ & $\begin{array}{ll}43 & 12\end{array} \mid$ & $\begin{array}{lll}43 & 11\end{array}$ & $3978 \frac{1}{2}$ & 385 \\
\hline & & 19 & 1810 & 194 & & & $\left\{\begin{array}{ll}17 & 0\end{array}\right\}$ & $\begin{array}{ll}20 & 6\end{array}$ & $21 \quad 4$ & 1411 & $1335 \frac{1}{4}$ & 129 \\
\hline $\begin{array}{rr}30 & 6\end{array}$ & $32 \quad 11$ & 32 & 3315 & 3212 & $32 \quad 9$ & \begin{tabular}{|ll}
19 & 10 \\
33 & 10
\end{tabular} & $\begin{array}{ll}18 & 13 \\
32 & 12\end{array}$ & $\begin{array}{rr}18 & 15 \\
33 & 0\end{array}$ & $\begin{array}{rr}17 & 8 \\
32 & 13\end{array}$ & $\begin{array}{rr}18 & 11 \\
32 & 8\end{array}$ & $\begin{array}{l}1701 \frac{1}{8} \\
2956\end{array}$ & $\begin{array}{l}165 \\
286\end{array}$ \\
\hline $\begin{array}{ll}33 & 4\end{array}$ & 34,10 & $\begin{array}{ll}35 & 1\end{array}$ & $34 \quad 0$ & 3115 & 304 & 3015 & $\begin{array}{ll}28 & 9\end{array}$ & $24 \quad 11$ & 24,11 & 286 & $2580 \frac{1}{8}$ & 250 \\
\hline $\begin{array}{ll}42 & 3\end{array}$ & $\begin{array}{ll}43 & 10\end{array}$ & 44 & $43 \quad 13$ & $43 \quad 3$ & 441 & 4412 & $44 \quad 6$ & & & 428 & $3865 \frac{1}{8}$ & \\
\hline & & $28 \quad 6$ & & $28 \quad 14$ & $\begin{array}{ll}28 & 11\end{array}$ & $28 \quad 2$ & $28 \quad 7$ & $27 \quad 0$ & $25 \quad 5$ & $27 \quad 12$ & $\mid \begin{array}{l}0000 \frac{\overline{2}}{2} \\
2526 \frac{1}{2}\end{array}$ & 245 \\
\hline $25 \quad 2$ & $\left|\begin{array}{ll}26 & 11\end{array}\right|$ & $26 \quad 6$ & $\begin{array}{ll}26 & 7\end{array}$ & $26 \quad 3$ & 2513 & $26 \quad 4$ & 260 & 2512 & $24 \quad 15$ & $25 \quad 12$ & $2343 \frac{1}{4}$ & 227 \\
\hline
\end{tabular}

$\S$ Replaced February 25th, by Daffodil, calved February 20th.

|I Slipped calf October 15th, but continued milking.

IT Replaced December 23rd, by Kate, calved December 20th. 
EXPERIMENTS

TABLe XIII.-YIELD OF

Lot 2.-20 Cows.

21. Susan* ........ June 12 June 14 1428

22. Countess ....... Nov. 23 Nov. 2845

23. Nina .......... Oct. 31 Nov. 837

24. Jane .......... Nov. 29 Nov. 3023

25. Charmer ....... Aug. 30 Sept. 336

26. Nancyt ......... Sept.

27. Nelly .......... Dec.

28. Princess.....+ April 29 May

9 Sept. $10 \quad 30 \quad 15 \quad 28$

$\begin{array}{llllll}2 \text { Dec. } & 6 & 39 & 12 & (41\end{array}$

Average milk per head per day.

29. Bright Eye ...... June

31. Empress........ Oct.

$\begin{array}{lllllll}17 & \text { June } & 23 & 32 & 1.0 & 28\end{array}$

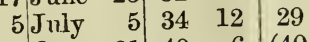

18 Oct. $21 \quad 40 \quad 6 \quad(40$

32. Julia $\ldots \ldots \ldots \ldots$ Nov.

\begin{tabular}{l|l|ll|l}
16 & Nov. 17 & 27 & 0 & $(29$
\end{tabular}

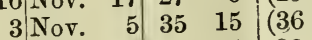

33. Scrutable ....... Nov.

\begin{tabular}{r|r|r|} 
34. May Day ........ July & 4 July & 5 \\
35. Liddy ......... & Dec. 11 Dec. 14 \\
\hline
\end{tabular}

36. Welcome ....... Nov. 24 Nov. 28

\begin{tabular}{rr|rr|rr}
27 & 4 & 22 & 7 & 21 & 11
\end{tabular}

37. Ne plus ultra§... July

38. Cowslip $\| . . . .$. April 1 April 4

39. Russet Belle .... March 18 March 20 40. Ophir $\uparrow$....... July 26 August 1

Average ....

$\begin{array}{llll}45 & 12 & (46\end{array}$

46

5

Experimental period.

\begin{tabular}{rr|rr|rr|rrrrrrrrr}
35 & 15 & 23 & 6 & 20 & 5 & 20 & 6 & 21 & 1 & 20 & 15
\end{tabular}

$4.31 \quad 9$

21

\begin{tabular}{rr|rr|rr|rr|rr|rr}
38 & 9 & 27 & 9 & 21 & 0 & 19 & 14 & 19 & 4 & 19 & 7 \\
34 & 1 & 28 & 6 & 20 & 3 & 19 & 3 & 17 & 10 & 15 & 4 \\
\hline 33 & 14 & 30 & 6 & 27 & 7 & 26 & 14 & 26 & 7 & 25 & 13
\end{tabular}

* Replaced January 11th, by Dewdrop, calved January 6th.

+ Bought as newly-calved at this date; exact date of calving not known. Replaced February 22nd, by Gypsy, calved January 30th. (See Note $\$$, Lot 1 ).

¥ Replaced January 24th, by Emma, calved January 2nd. 
We will next give the results obtained on changing from cloversilage to meadow-grass-silage :-

On March 14 the experiment with cows on clover-silage terminated, and that on meadow-grass-silage at once commenced, and was continued for a period of six weeks. In order not to interfere with the yield of milk by a sudden change of food, a mixture of three parts clover-silage and one part grass-silage was given during the first seven days, and a mixture of half clover- and half grass-silage during the next seven days, after which grass-silage only was given.

Table XIV shows the average amounts of the different foods consumed per head per day, within each week, by each of the two lots of 20 cows.

\section{EXPERIMENTS WITH COWS.}

Table XIV.-A Arerage Fodd Consumed per Head per Day. Second Period; Six Weeks, March 15 to April 25.

\begin{tabular}{l|l|l|l|l|l|}
\hline \multirow{2}{*}{ Week ending } & \multicolumn{3}{|c|}{ Arerage food giten per head per day. } & Total food \\
weighed \\
off.
\end{tabular}

Lot 1.-20 Cows; Part Clover-silage, part Meadow-grass-silage.

\begin{tabular}{|c|c|c|c|c|c|c|}
\hline 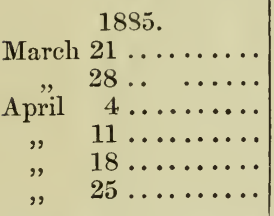 & $\begin{array}{c}\text { lbs. } \\
4 \\
4 \\
4 \\
4 \\
4 \\
4\end{array}$ & $\begin{array}{r}\text { Ibs. } \\
4 \\
4 \\
4 \\
4 \\
4 \\
4\end{array}$ & $\begin{array}{l}\text { lbs. } \\
9 \frac{3}{7} \\
8 \\
7 \frac{5}{7} \\
7 \\
7 \\
7\end{array}$ & $\begin{array}{l}\text { lbs. } \\
50 \\
50 \\
50 \\
50 \\
42 \frac{1}{7} \\
41 \frac{3}{7}\end{array}$ & $\begin{array}{l}\text { lbs. } \\
\text { (1) } 11 \frac{3}{7} \\
\text { (1) } 20 \\
\text { (2) } 20 \\
\text { (4) } 11 \frac{3}{7} \\
\text { (20) } 6 \frac{3}{7} \\
\text { (20) } 17 \frac{1}{7}\end{array}$ & $\begin{array}{l}\text { lbs. } \\
408 \\
197 \\
329 \\
395 \\
434 \\
75 \ddagger\end{array}$ \\
\hline $\left.\begin{array}{c}\text { Average per head } \\
\text { per day......... }\end{array}\right\}$ & $\cdots$ & .. & .. & .. & $\cdots$ & $2 \cdot 19$ \\
\hline
\end{tabular}

Lot 2.-20 Cows; Mangels as before.

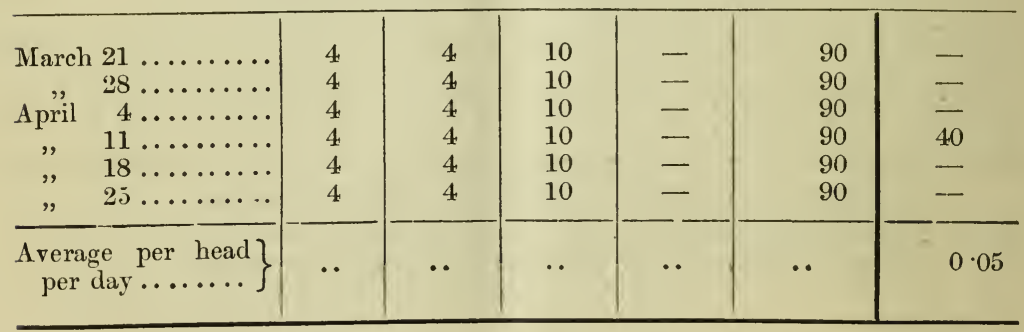

* $\frac{1}{2}$ hay and $\frac{1}{2}$ oat straw.

+ The figures in parentheses show how many cows received mangels.

\$ During this period most of the unconsumed food was distributed among the other cows of the lot, and consumed. 
It will be seen that both lots received the same amount of cottoncake and bran as before; and Lot 2 also the same amount of chaff and mangels as before. In fact, there was no change whatever in the food of the 20 cows receiving mangels. The cows receiving silage were also at first supplied with the same amounts of both chaff and silage as before; but they did not consume them, and it was found necessary to reduce the quantity of chaff, until, during the last three weeks of the period, the allowance was only $7 \mathrm{lbs}$. instead of $10 \mathrm{lbs}$. per head per day; and during the last fortnight the amount of silage was reduced by nearly one-fifth, and some mangels were given to all instead of only to a few, of the cows receiving silage. It will be observed, indeed, that throughout the experiment a good deal of food, chiefly silage and chaff, was left unconsumed.

In the case of the experiment with clover-silage as against mangels, it was concluded that the silage, when given to cows in quantity containing an amount of dry matter corresponding to that in the mangels, was not so suitable for milk production as the succulent mangels, which only contained about half the percentage of dry matter, and a very much less proportion of woody fibre. It was also concluded that probably a better result would have beẹn obtained if a smaller quantity of the silage, with some mangels, had been given. The meadow-grass-silage contained a still higher percentage of dry matter than the clover-silage, and no doubt a much higher percentage of woody fibre. It also contained only about two-thirds as much nitrogen as the clover-silage; though the quantity of it consumed contributed nearly as much nitrogen as the quantity of mangels consumed by the other cows; and doubtless the silage supplied a larger amount of albuminoid nitrogen than the mangels, that is, a larger amount in a condition available as food.

It is not to be wondered at, therefore, that with silage containing still more dry matter, and especially still more woody fibre, the cows should not consume so much, and that they should also require much less chaff.

Table XV (p. 48) shows, for each of the 20 cows receiving the meadow-grass-silage, the average yield of milk per day, during each of six weeks of the experiment; and Table XVI (p. 49) shows the same particulars for the 20 cows receiving mangels. In each case, there is also given the average yield per day during the preceding 13 weeks of those of the cows which had gone through the whole of the previous experiment, or for a shorter period for those which had been brought in during its progress; also the average yield during the immediately preceding week. Finally, there is given the average yield per day, and the aggregate yield (both in lbs. and in gallons), of each cow, and of each lot, during the whole period of six weeks of the second experiment. 


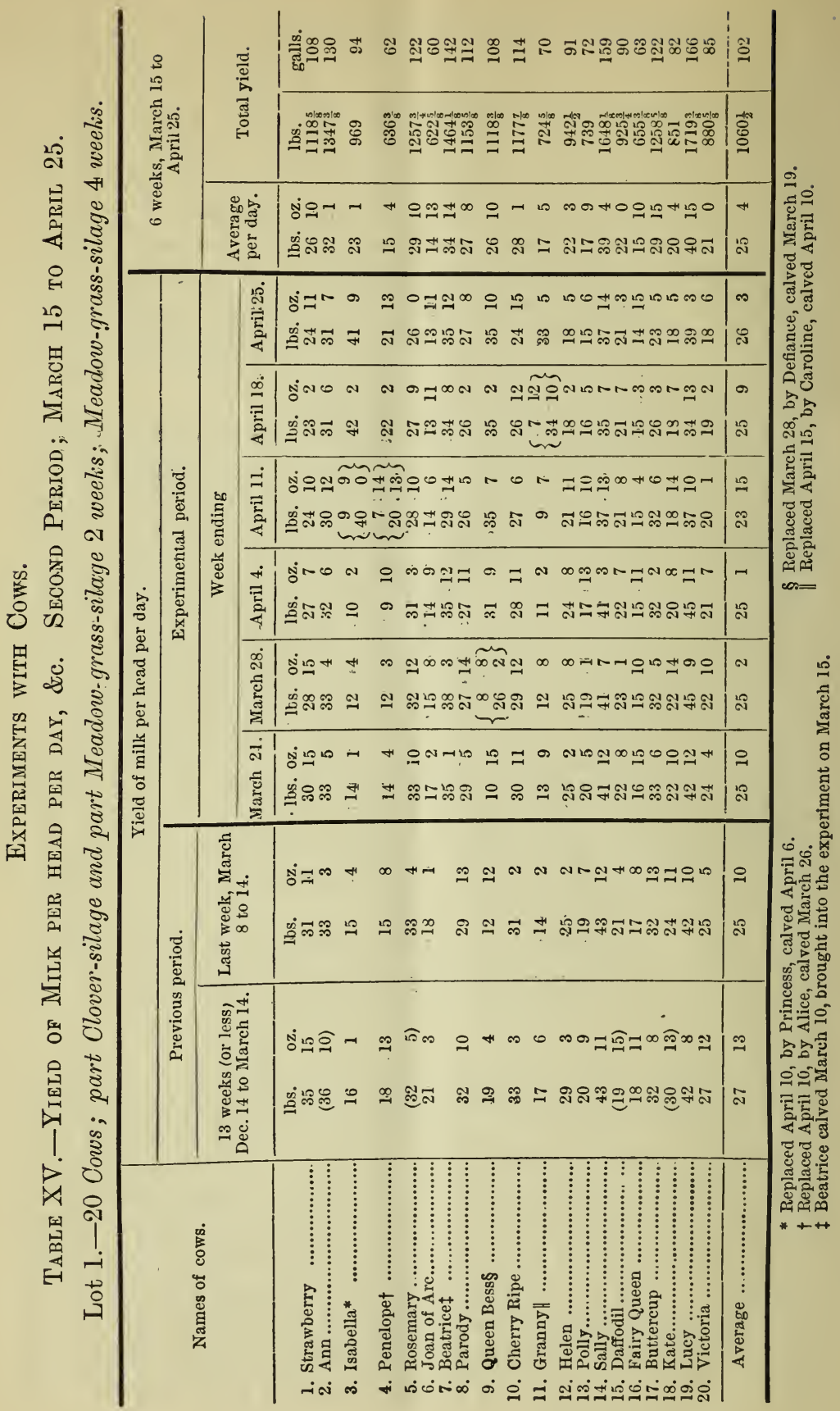


EXPERIMENTS ON ENSILAGE.

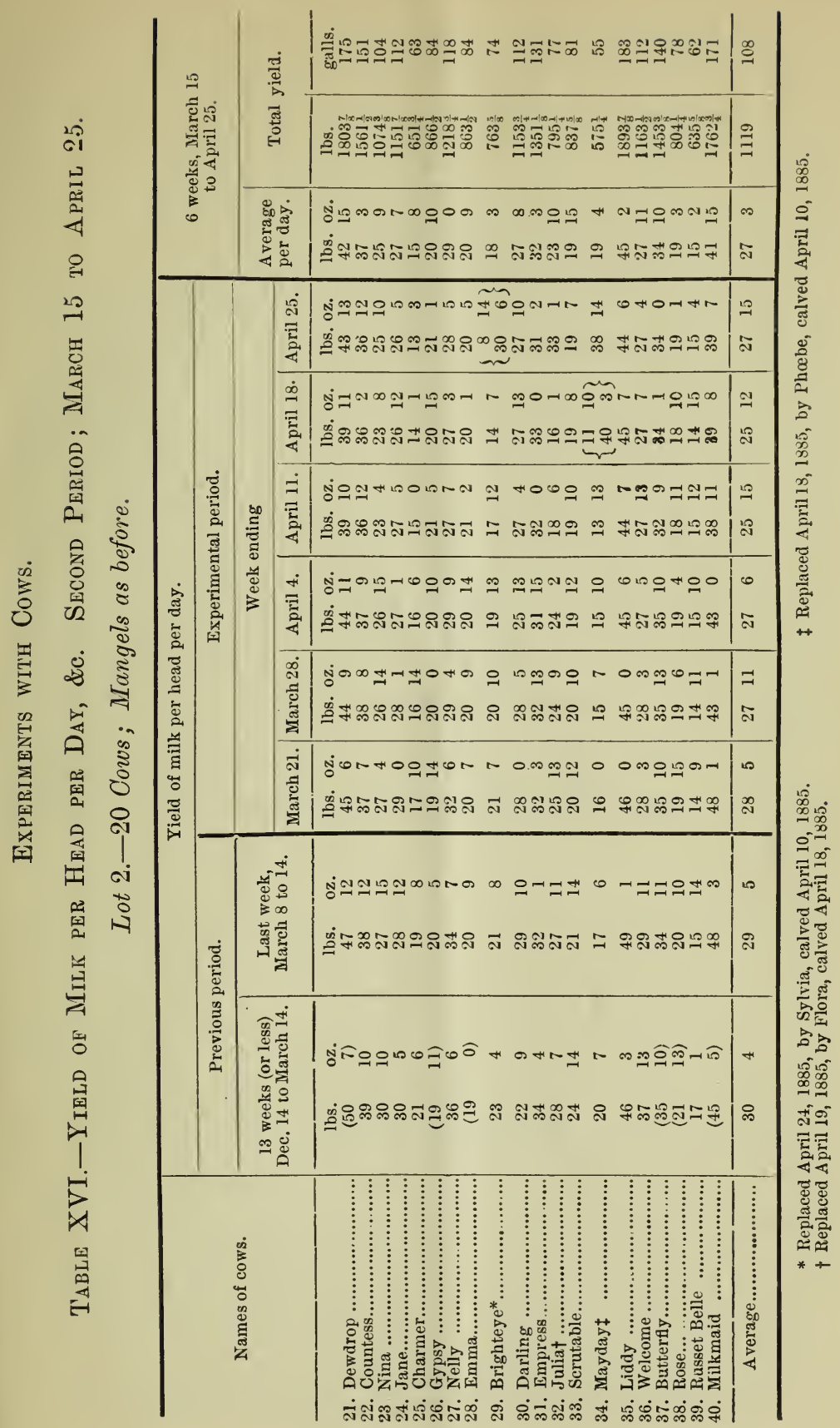


In the first place, 'lable XV (p. 48) shows that, of the 20 cows on silage, four became dry during the experiment; one in the second, two in the fourth, and oue in the fifth week, and they were replaced by others; three out of the four of which gave a higher yield of milk than the average of the lot. Table XVI (p. 49) shows that, of the 20 cows on mangels, three became dry, one in the fifth, and two in the sixth week; and they were in each case replaced by others which yielded more than the average of the lot.

In the week prior to the commencement of this second experiment, the average yield of the silage-fed cows was nearly $3 \frac{3}{4} \mathrm{lbs}$. per head per day less than that of the cows on mangels; and although during the six weeks of the experiment the cows receiving the meadow-grasssilage gave a less actual quantity of milk than those on mangels, they fell off in yield less, and gave, on the average of the whole period, only 2 lbs. instead of as at the beginning nearly $3 \frac{3}{4}$ lbs. less milk per head per day than the mangel-fed cows. Both lots fell off in yield during the fourth week, probably under the influence of the weather. But whilst the silage-fed cows recovered again in the next week, coincidently with a reduction in the amount of silage and its replacement by some mangels, aided by the introduction of fresh cows, those on mangels did not recover until a week later, and then not to their. original yield, notwithstanding three high-yielding cows had been brought in.

So far as the yield of milk is concerned, the evidence is, therefore, not adverse to the silage, when used in moderate quantity, according to the amount of solid and digestible matter it contains.

In the first experiment, the cows receiving clover-silage in rather large amount gave rather less milk than those on mangels; but, on the other hand, they gave a considerable increase in liveweight, whilst those on mangels as a whole lost in weight. Owing to the numerous changes in the cows during the course of the experiments, it happens that there are only 12 of the original silage-fed cows, and only 11 of the original mangel-fed cows, the weights of which can be traced through both periods of experiment. The cows were weighed soon after the commencement of the experiment with clover-silage, in December, 1884 ; again at the end of that experiment, when that with the meadow-grass-silage commenced; and, lastly, at the conclusion of the second period. We do not propose to enter fully into the subject of the increase or loss in weight of the animals on the present occasion, but only to refer to the general character of the results in their comnection with the greater or less yield of milk by the different lots, over the different periods.

As already said, the cows on clover-silage increased in weight con- 
siderably, and of the 12 of the original 20 which continued throughout both experiments, every one increased when on the clover-silage. On the other hand, of the 11 of the mangel-fed cows which remained throughout the two periods, only 4 increased during the first period, and on the average the lot lost in weight. During the second period, however, when the meadow-grass-silage was used, only 3 of the 12 cows increased at all, two of them very little, and the lot as a whole lost in weight considerably; whilst of the 11 cows of the mangel lot, 7 now increased, and the lot as a whole increased in weight.

From the whole of the results of the experiments on the feeding of cows with silage, it would appear that the clover-silage given in such large quantity was more favourable for meat-production, and less for milk-production, than the mangels. On the other hand, when the meadow-grass-silage was used, the animals did not give more milk, but they lost in weight. There can be no doubt that the grass-silage was inferior as food to the clover-silage: and it is to be supposed that the favourable maintenance in the yield of milk on the grass-silage compared with that of the cows on mangels over the same period, is at any rate partly to be attributed to a drain on the flesh and fat previously stored up by the animals. So far as this may take place, it obviously does not necessarily follow that there will be an immediate falling off in the yield of milk on changing to an inferior food. It is known that a badly-fed cow will reduce in condition very much when suckling a calf; and the same thing may happen when the cow is milked. In fact, the comparative values of different foods for cows cannot be measured by the yield of milk alone; but the increase or loss in weight must also be taken into account.

10.-Character and Composition of the Milk from the Different Foods.

Owing to the large amount of additional work in the Rothamsted Laboratory in connection with other branches of the ensilage experiments, it was found impossible to devote sufficient time and attention to obtain a complete series of comparative analyses of the milk yielded by the cows on the different foods. Still, sufficient has been done clearly to indicate the comparative characters of the different milks.

Table XVII (p. 52) shows the percentage of total solids, in 13 samples of the morning milk, of each of the two lots of cows, taken at intervals during the 10 weeks from January 14 to March 2.5; Lot 1 having silage, and Lot 2 mangels containing a corresponding amount of dry matter; each lot having the same amount of other foods in addition. The table also shows the percentages of mineral matter, or ash, in the last eight samples for each lot. 
Table XVII.-Percentages of Total Solids, and Mineral Matrer (ash), in the Morning Milk of the Cows.

Lot 1.-Silage. Lot 2.-Mangels.

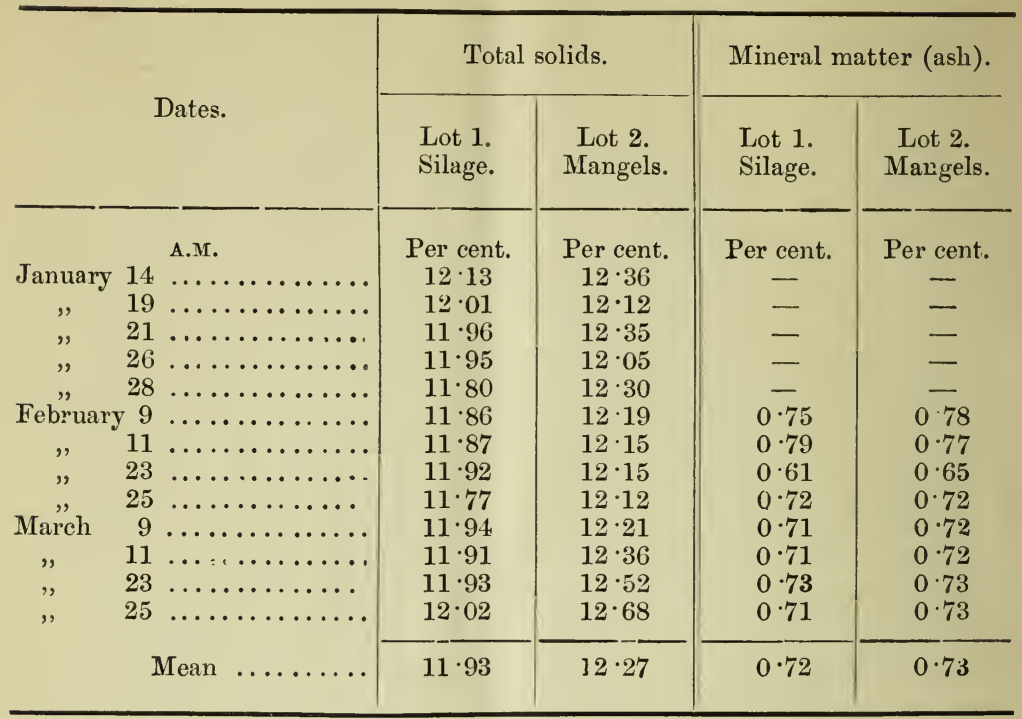

Table XVIII (p. 53) shows, not only the percentages of total solids and of mineral matter, but also the percentages of butter-fat, and the specific gravity, of buth the morning and the evening milk of each lot of cows, on six different days from April 7 to April 22. It may be stated that the percentage of fat was frequently determined by Marchand's lacto-butyrometer; but the results given in the table are calculated by Fleischmann and Morgen's formula, from the amount of total solids, and the specific gravity. The results obtained by the lacto-butyrometer, although very useful, are admittedly only approximative; and, as Dr. P. Vieth has shown by a very comprehensive investigation of the subject, the deviations from the amounts as determined by more exact methods, are greater in the case of results obtained by it, than in those obtained by calculation from the total solids and the specific gravity.

Referring to the results in Table XVII, it should be observed that Lot 1 were receiving clover-silage during the periods of sampling from January 14 to March 11, and a mixture of clover-silage and meadow-grass-silage when the samples of March 2:3 and March 25 were taken. They were also receiving meadow-grass-silage at the six periods of sampling to which the results given in Table XVIII refer. Lot 2, however, received mangels thronghont. 


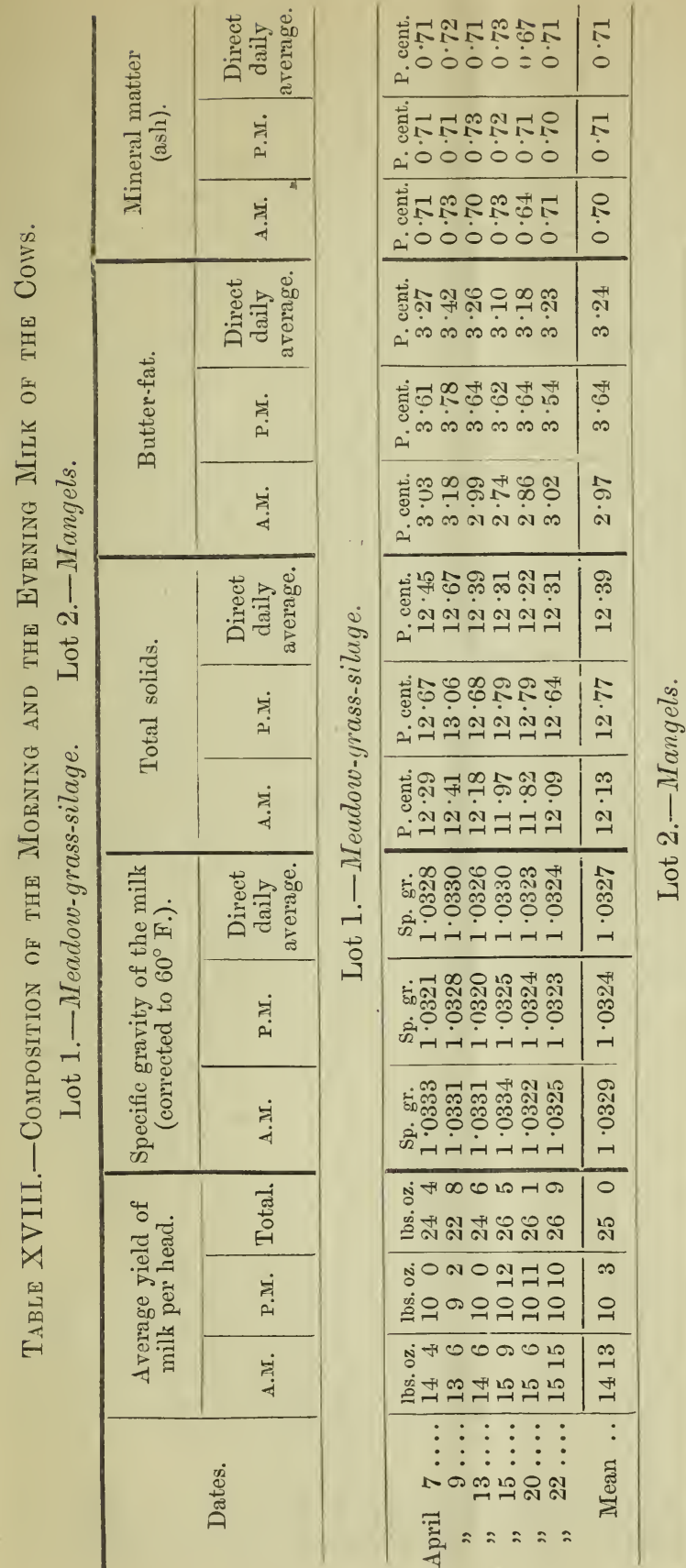

\begin{tabular}{|c|c|}
\hline 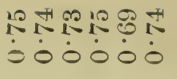 & $\dot{0}$ \\
\hline 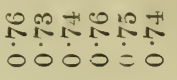 & $\overbrace{10}^{0}$ \\
\hline 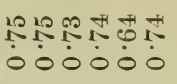 & $\stackrel{i}{\dot{0}}$ \\
\hline 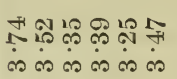 & in \\
\hline
\end{tabular}

ఝุ.

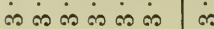

ถ⿻ำ

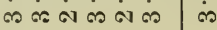

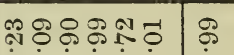

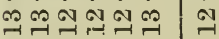

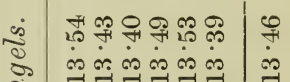

।

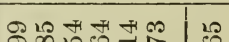

की

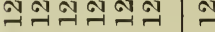

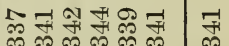

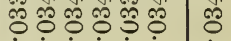

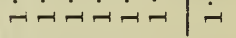

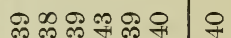

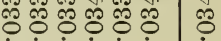

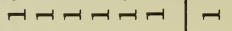

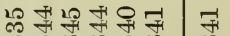

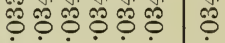

$\neg \neg-\neg-1$

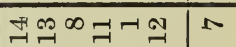

กรูง

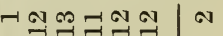

커으음으크키

$m-1=102000$

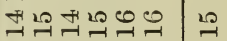

$::::::$ :

$:::::$

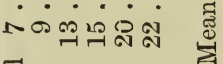

崩 ニ ニ ニ ล

D 2 
It is seen that the mean percentage of total solids in the 13 samples of the morning milk of the silage-fed cows, taken from January 14 to March 25, is 11.93 against $12 \cdot 13$, the mean of the six samples of their morning milk taken from April 7 to April 22. Again, the mean of the 13 samples of the morning milk of the mangel-fed cows, taken from January 14 to March 25, was $12 \cdot 27$, against 12.65 during the period from April 7 to April 22. There was thus, in both cases, an increase in the percentage of total solids as the season adranced. But, as the increase was even greater with the mangel- than with the silage-fed cows, it is obvious that the result is due to the season, and not, in the case of Lot 1 , to the change from clover- to meadowgrass-silage.

Still confining attention to the results relating to the morning milk, which is well known to be poorer than evening milk, it is seen that at each of the 19 periods of sampling to which Tables XVII and XVIII refer, the milk of the mangel-fed cows shows a higher percentage of total solids than that of the silage-fed cows. It also shows, almost without exception, a slightly higher percentage of mineral matter.

Turning now to the more detailed composition, as recorded in Table XVIII, it is seen that the milk of both lots shows, on the average, indeed in nearly every individual case, a slightly lower specific gravity in the afternoon than in the morning. The afternoon milk shows, on the other hand, uniformly a considerably higher percentage of both total solids and butter-fat; and generally a somewhat higher percentage of mineral matter also. Thus, whilst the mean percentage of total solids in the morning milk of the silage-fed cows is $12 \cdot 13$, in their evening milk it is 12.77 , or 0.64 higher ; and whilst the mean percentage of total solids is 12.65 in the morning milk of the mangel-fed cows, it is 13.46 , or 0.81 higher, in their evening milk. Again, whilst the mean percentage of butter-fat in the morning milk of the silagefed cows is 2.97 , in their evening milk it is $3 \cdot 64$, or 0.67 higher; and whilst the mean percentage of butter-fat in the morning milk of the mangel-fed cows is $3 \cdot 15$, in their evening milk it is 3.88 , or 0.73 higher. It is thus seen that, in the case of both lots of cows, the higher percentage of total solids in the evening milk very closely corresponds with the increased amount of butter-fat in the evening milk.

The first three columns of Table XVIII, show the average yield of milk per head of each lot of cows, in the morning, in the evening, and for the whole day, at each of the six periods of the sampling and the analysis of the milk. It will be seen that there was little more than two-thirds as much of the richer evening milk as of the poorer morning milk.

The "direct daily averages," of specific gravity, and of the percentages of total solids, butter-fat, and mineral matter, as given in the 
third column of the respective divisions of the table, are calculated from the quantities, and the composition, of the morning and the evening milk, respectively. According to these results, the average percentage of total solids in the total daily milk of the silage-fed cows was, over the six periods, 12.39 , against 12.99 , or 0.60 higher, in that of the mangel-fed cows. And the average percentage of butter-fat in the daily milk of the silage-fed cows is 3.24 , against 3.45 , or 0.21 higher, in the milk of the mangel-fed cows. There is thus less difference between the average amount of total solids in the milk of the two lots of cows, than there is between the morning and evening milk of the same cows; and there is very much less difference in the average amount of butter-fat in the milk of the two lots, than there is between the amount in the morning and the evening milk of the same cows. It may be added that the average percentages of total solids, and of butter-fat, agree very fairly with those given by Dr. Vieth for the average milk of the same period of the year; those of the silage-fed cows being somewhat below, and those of the mangel-fed cows above his average.

Upon the whole, the analytical results clearly show that the milk of the mangel-fed cows throughout contained higher amounts of both total solids, and butter-fat, than that of the silage-fed cows. Yet, quite consistently with the observation of others on the same point, the milk of our silage-fed cows was judged, both by colour and by taste, to be richer than that of the mangel-fed cows. The milk of the silage-fed cows possessed a slight, but not at all disagreeable, flavour, which may be described as hayey, and which could readily be detected by some, but not by others. The butter from the milk of the silage-fed cows was also mucb yellower than that from the milk of the mangel-fed cows; but there was no perceptible distinction between the two as to taste.

With these results we close the record of our silage experiments for the present.

\section{Summart, and General Conclusions.}

1. It would require a larger area of land to obtain a given quantity of dry substance of food in crops grown for ensilaging, than to obtain the same quantity in roots.

2. The substitution of ensilage-crops for roots on a large scale would necessitate a considerable change in the course of cropping. It would lessen the area under cleaning crops, and consequently lessen the area suitable for growing grain for the market.

3. Where ensilaging is only adopted instead of hay-making, it is improbable that it will be substituted for it entirely, and if only 
partially, the process would only have a comparatively limited application. Or, if it be extended to the natural and artificial grasses usually fed on the land, an expensive mode of feeding would be substituted for an economical one.

4. Neither in the case of red-clover, nor in that of meadow-grass, was the loss of dry substance of food in the silo so great as has frequently been supposed. It was, so far as can be judged, much about the same as in a hay rick.

5. There was some total loss of nitrogenous substance; but there was a much larger amount of it degraded from the albuminoid condition to compounds incapable of forming the nitrogenous substances of animal increase, or of milk.

6. The results obtained do not confirm the conclusion that woody fibre of a given degree of induration is rendered more soluble, and consequently more digestible.

7. In a comparative experiment with fattening oxen, a given amount of dry substance in red-clover-silage was found to be practically equal to the same amount of dry substance in a mixture of clover-hay-chaff and swedes, given in the proportion of 12 parts chaff and 50 parts swedes.

8. The amount of dry substance of food required by a cow of say about $1200 \mathrm{lbs}$. live-weight, when in milk, will vary considerably according to the character of the food, the temperature to which the animal is exposed, its yield of milk, and other circumstances. But it will seldom be less than 25 lbs. per head per day, and will seldom exceed $30 \mathrm{lbs}$.

9. When a milking cow is supplied with fair proportions of chaff and roots, with fair proportions of purchased food, such as cake and bran, in addition, the home-grown food will approximately supply the requirements of the animal for mere sustenance, and approximately the whole of the purchased food will remain for milk production. It is a question for consideration, therefore, how far the supply of the purchased foods should be graduated according to the yield of milk of each individual cow.

10. In ordinary liberal feeding, food is always consumed in excess of the amount which, according to calculation, is actually required for sustenance, and for the production of fattening increase, or of milk.

11. Two or three times as much total dry substance, and six, seven, or more times, as much nitrogenous substance, will be contained in the milk of a cow yielding 3 gallons per day, as in the fattening increase of an ox of the same weight.

12. In a comparative experiment with milking cows, clover-silage was tried against mangels. 'T'wo lots of cows, of 20 each, had the same amounts of cake, bran, and chaff; one lot receiving besides, an 
average of nearly $49 \mathrm{lbs}$. of clover-silage, and the other lot an average of nearly $86 \mathrm{lbs}$. of mangels per head per day. Over a period of 13 weeks, the cows having clover-silage yielded an average of 25 lbs. 12 ozs. of milk per head per day, and those having mangels gave an average of $27 \mathrm{lbs} .5$ ozs. per head per day.

13. There was more nitrogenous substance, and rather more total dry substance, but more of this was woody fibre, in the quantity of clover-silage consumed, than in the mangels. The silage was, therefore, when given in such large proportion, less suitable for milkproduction than the more succulent mangels. The result was that the cows on the silage showed more tendency to fatten; and, in fact, though giving less milk, they gained in live-weight, whilst the mangel-fed cows slightly lost in weight.

14. It is probable that, if a portion of the clover-silage had been replaced by an amount of mangels containing a corresponding quantity of dry matter, the yield of milk would have been greater, and the tendency to increase in live-weight would have been less.

15. In a second experiment with the two lots of cows of 20 each, and extending over six weeks, the same standard foods were given as before; but, in addition, the one lot now received meadowgrass-silage, and the other mangels as before. Compared with the clover-silage, the meadow-grass-silage would contain still more woody fibre, and it contained little more than two-thirds as much nitrogenous substance. It was accordingly found that the animals would not consume so much chaff, nor the whole of the silage given to them. Some mangels were therefore given with the silage, when they consumed it better. Both lots of cows slightly declined in yield of milk during this period, the silage-fed cows rather less than the others. There was, however, but little difference in the yield of the two lots; but whilst the silage-fed cows now lost in weight, the mangel-fed cows slightly gained.

16. When analysed, the milk of the mangel-fed cows invariably showed a higher percentage of both total solid matter, and butter-fat, than that of the silage-fed cows.

17. The afternoon milk of both lots of cows always gave higher percentages of both total solid matter, and butter-fat, than the morning milk; and the excess of solid matter in the afternoon milk very closely corresponded with its excess of fat.

18. There was more difference in the percentage of both total solid matter and fat, between the morning and the evening milk of the same lot of cows, than between the milk of the two lots taken at the same time of day.

19. There can be no doubt that good food may be preserved in a favourable state for future use by being properly ensilaged. But the 
results obtained at Rothamsted do not favour the idea that produce which is itself not good food, can be made good food by being ensilaged.

20. Good ensilage, given in such amount as to supply the sam quantity of dry substance as would be given in chaff and roots, is no doubt a very good food for fattening oxen.

21. Good ensilage, given in less proportion, and in conjunction with roots, with the ordinary dry foods in addition, is no doubt a very good food for milking cows.

22. In conclusion, it is hoped that the details which have been given of the first year's experiments on ensilage at Rothamsted, will afford some useful basis for the consideration of those who may be deliberating whether or not to adopt the system. 

